\title{
Bankacı Eğitim Kavramı Bağlamında Türkiye'de Din Eğitiminin Eleştirel Analizi
}

\section{A Critical Analysis of Religious Education in Turkey in the Context of Banking Concept of Education}

\author{
Arş. Gör. Mustafa ÇETíN1', Doç. Dr. Bayramali NAZIROĞLU² \\ 1 Artvin Çoruh Üniversitesi/ Ilahiyat Fakültesi/ Din Eğitimi \\ • mustafacetin@artvin.edu.tr • ORCID > 0000-0002-2519-7394 \\ ${ }^{2}$ Recep Tayyip Erdoğan Üniversitesi/ Ilahiyat Fakültesi/ Din Eğitimi \\ •bayramali.naziroglu@erdogan.edu.tr•ORCiD > 0000-0003-2091-614X
}

Makale Bilgisi / Article Information

Makale Türü / Article Types: Araştırma Makalesi / Research Article

Geliş Tarihi / Received: 4 Eylül / September 2021

Kabul Tarihi / Accepted: 10 Kasım / November 2021

YIl/Year: 2021 | Sayı - Issue: 51 |Sayfa / Pages: 201-226

Atıf/Cite as: Çetin, M. ve Nazıroğlu, B. “Bankacı Eğitim Kavramı Bağlamında Türkiye’de Din Eğitiminin Eleştirel Analizi - A Critical Analysis of Religious Education in Turkey in the Context of Banking Concept of Education". Ondokuz Mayıs Üniversitesi

Illahiyat Fakültesi Dergisi- Ondokuz Mayıs University Review of the Faculty of Divinity 51, Aralık 2021: 201-226. https://doi. org/10.17120/omuifd.991175

İntihal /Plagiarism: Bu makale, en az iki hakem tarafından incelendi ve intihal içermediği teyit edildi. / This article has been reviewed by at least two referees and scanned via a plagiarism software. http://dergipark.gov.tr/omuifd

Copyright @ Published by Ondokuz Mayıs Üniversitesi, Illahiyat Fakültesi - Ondokuz Mayıs University, Faculty of Divinity, Samsun, Turkey. All rights reserved. 


\section{BANKACI EĞITIM KAVRAMI BAĞLAMINDA TÜRKIYE'DE DIN EĞITIMININ ELEŞTÍREL ANALIZi[i]}

ÖZ:

Bu makalede geleneksel ve modern eğitim anlayışlarına karşı kuramsal bir eleştiri olarak 20. yüzyılda ortaya çıkmış olan eleştirel pedagojinin anahtar kavramı olan "bankacı eğitim” kavramı din eğitimi açısından yorumlanmış, Türkiye'deki örgün din eğitimi uygulamaları bağlamında bu kavram açısından anlamlı sayılabilecek konular ve sorunlar üzerine bir değerlendirme yapılmıştır. Nitel araştırma mantığıyla hazırlanmış çalışma; başta Freire olmak üzere eleştirel pedagoji alanyazınının incelenmesi ve Türkiye'deki örgün din eğitiminin durumuna ilişkin metin, doküman ve raporların "bankacı eğitim" kavramı bağlamında eleştirel bir yaklaşımla yorumlanmasına dayalıdır. Çalışmada öncelikli olarak eleştirel pedagojinin teorik temeline değinilmiş ve bu yaklaşımın din eğitimi bağlamındaki olası uzanımları tartışılmıştır. Daha sonra "bankacı eğitim” kavramı perspektifinden örgün din eğitiminin bazı güncel sorunları teşhis edilmeye çalışılmıştır. Bu bağlamda din eğitiminde bankacı eğitim olarak nitelenebilecek sorunlar; "nesnel bilgi kaygısı", "rekabet ve sıralamaya dayalı ölçme-değerlendirme anlayışı" ve "teknik-meslekî bakış açısı” olarak üç başlık altında ele alınmış, sonuç bölümünde bu sorunların giderilmesine yönelik olarak eleştirel pedagojinin bakış açısından hareketle öneriler sunulmuştur.

Anahtar Kelimeler: eleştirel pedagoji, eleştirel eğitim felsefesi, bankacı eğitim, meslek odaklı eğitim, teknik bilgi, din eğitimi, İslam din eğitimi, din eğitimi felsefesi, Freire, özgürleştiren eğitim.

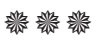

\section{A CRITICAL ANALYSIS OF RELIGIOUS EDUCATION IN TURKEY IN THE CONTEXT OF BANKING CONCEPT OF EDUCATION}

\section{ABSTRACT:}

In this paper, we propose the banking concept of education of critical pedagogy as a useful tool for addressing the some current issues in religious education in Turkey. As a key concept of critical pedagogy that emerged in the 20th century as a theoretical criticism towards the traditional and modern approaches of education, banking concept of education deserves to be interpreted in terms of religious education. In accordance with the purpose, the theoretical grounds of the critical

[1] Bu makale, Mustafa Çetin tarafından Doç.Dr. Bayramali Nazıroğlùnun danışmanlığında hazırlanmakta olan doktora tezinden üretilmiştir. 
pedagogy has been problematized and discussed the possible contributions of this approach for optimizing the efficiency and effectiveness of the religious education. The article has been conducted in the frame of qualitative research design in order to determine a starting point for a critical pedagogical paradigm in religious education. In order to estimate the value of critical pedagogy for religious education, we firstly reviewed the literature of critical pedagogy - predominantly Paulo Freire's works-. Secondly, we interpreted several related texts, documents and reports that subject the current situation in religious education practices in Turkey in a critical manner. As a result, we consider the problems of current religious education practices that are able to be debated within the scope of banking concept; "overemphasizing the objective knowledge", "competition and grading-orientedness in measurement and evaluation" and "technical-career focuseness". In the conclusion, we discussed how the critical pedagogy can offers conceptional and theoretical contribution for overcoming these problems.

Keywords: critical pedagogy, critical philosophy of education, banking model, banking concept of education, professional-oriented education, technical knowledge, religious education, Islamic Education, philosophy of religious education, Freire, emancipatory education.

\section{释释 \\ GíRiş}

Tarih öncesi dönemlerden günümüze dek süregelen en önemli insanî gerçeklikler arasinda yer alan inanma duygusu ve din olgusu (Eliade, 2003, s. 21), Tanr1 ile insan arasında dolaysız ilişkiye bağlı bireysel ve aşkın bir tecrübe olmasının yanı sıra yaşamın bütününü kuşatan bir insancıllık ve toplumsallık vizyonunu da beraberinde taşımaktadır. İnsanın anlam arayışı, özgürlük ihtiyacı ve kendilik bilinci gibi varoluşsal duyarlılıklarına hitap eden din, bu yapısıyla bireyi öz varlığı ve kişisel yaşantıları kadar içinde yaşadığ 1 toplum ve insanlık şematiği içerisinde de anlamlandırarak ona dünya üzerindeki konumunu, değerini ve misyonunu hatırlatan bir dünya görüşü vizyonu oluşturur. İnsanı, "Allah’’n (c.c.) yeryüzündeki halifesi” olarak adlandıran (el-Bakara 2/30, el-En'âm 6/165) ve onu iyiliği özendirmek ve kötülükten alıkoymakla mükellef kılan (Âl-i İmrân 3/104) İslam dini, bireysel manevî alanın ötesine geçen perspektifiyle Müslüman kişiliğin iç dünyası ile çevresi, kişisel alanıyla toplumsal alan ve dünyevî olanla uhrevî olan arasında kurması gereken dinamik iletişim sorumluluğunu vurgulamaktadır.

Genel anlamda din, özel anlamda ise İslam dini bağlamında dikkat çektiğimiz bu husus, din eğitimini de yakından ilgilendirmektedir. Dinî bilgi ve inanç alanı, manevî bir yaşamın inşasında en önemli unsur olmasının yanı sıra doğru bir eği- 
tim yaklaşımıyla pek çok felsefî kazanımı sağlayabilecek ve bireyin insanlık, özgürlük ve tekâmül yolunda yetkinleşme potansiyelini ortaya çıkarabilecek bir alandır. Din olgusunun, bireyin doğuştan getirdiği gizil güçleri işleterek geliştirme ve tekâmüle ulaştırmaya yönelik vizyonu açısından anlam ifade edebilecek boyutlarıyla eğitim süreçleri içerisinde yer bulması, din eğitimin amaçlarının hayata geçirilmesi açısından gerekli bir unsur olarak karşımıza çıkmaktadır. Böyle bir din eğitimi modeli; insanı yüzeysel, tek boyutlu ve mekanik bir düzlemde ele alan modern egemen eğitim anlayışlarının yıkıcı ve yozlaştırıcı etkilerini giderme ve bu olumsuz etkileri özgürlükçü, paylaşımcı, demokratik ve uyumlu bir yaşam kültürü yönünde değiştirme potansiyeline sahiptir. Yersiz müdahalelerden, sinırlandırmalardan ve dayatmalardan arınmış; özgürlük, paylaşım ve sosyal adaleti önceleyen bir din eğitimi anlayışının yetişen nesiller arasında daha insancıl ve eşitlikçi bir dünyaya dair farkındalık yaratacağı muhakkaktır. Bu nedenle İslam din eğitiminin amaçları belirlenirken kendilik bilinci, hayata anlam verme ve bireysel arınma gibi egzistansiyel ihtiyaçların (Yaran, 2001, s 84) yanı sıra adalet, eşitlik, demokrasi, özgürlük ve barış gibi toplumsal sorumluluk ve farkındalık ifade eden kazanımların da eğitim süreçlerine dahil edilmesi gerekmektedir.

Özgürlük, eşitlik, adalet, sorumluluk ve diyalog gibi kavramları eğitime bir temel ve çıkış noktası olacak şekilde ele alan ve yorumlayan eleştirel pedagojinin temelini oluşturan "bankacı eğitim” kavramı; din eğitiminde dinî bilgi müktesebatıyla toplumsal yaşam arasındaki kopukluğu ve eğitimin bir standartlaştırma aracı olarak kullanıldığı süreç ve uygulamaları teşhis etmek açısından önemli bir kavramsal işlevi yerine getirebilecek niteliktedir. Eğitiminde ezberci yaklaşımların terkedilmesi ve bireyi sosyal sorumluluk, sosyal farkındalık, empati, dayanışma ve yardımseverlik gibi insanî duyarlılıklarla buluşturacak bir pedagojik eksenin kurulabilmesi açısından gerekli olan bu husus; özellikle geleneksel tarzda ${ }^{[2]}$, kavramsal ve önermesel bilginin aktarımına dayalı din eğitimi uygulamalarının günümüz sorunlarına ilgisiz; bireyin özgürce gelişmesini, değişimini ve dönüşümünü gerçekleştirmekte başarısız ve hâlihazırda yaşadığımız hayatla inanç arasındaki köprüyü kurmada problemli olan noktalarını teşhis etmek açısından değerlendirilmeyi hak etmektedir. Bu bağlamda bu çalışma ile eleştirel pedagojinin özgür birey, toplumsal özne ve sosyal adaletin inşası yolunda engel olarak gördüğü bankacı eğitim kavramını din eğitimi açısından somutlaştırmak ve din eğitiminin güncel sorunlarını eleştirel pedagojinin temel varsayımları ışığında değerlendirmek amaçlanmaktadır. Nitel bir araştırma mantığına dayalı olan çalışma, başta eleştirel pedagojinin öncü isimlerinden olan Freire olmak üzere eleştirel pedagoji alanyazınının incelenmesi ve Türkiye'deki örgün din eğitiminin durumuna ilişkin metin, doküman

[2] Makale boyunca kullanacağımız "geleneksel eğitim” kavramı ile modernite öncesi zamanların skolastik karakterdeki öğretmen ve anlatı merkezli, özcü, daimîci ve mutlakiyetçi eğitim biçimleri kastedilmektedir. "Modern eğitim" kavramıyla ise ulus bilinci ve sanayi devriminin sonucu olarak eğitimin kitleselleşmesi, kurumsallaşması ve zorunlu hale gelmesiyle başlayan; ulusal müfredatlar ve sonuç odaklı standart ölçme-değerlendirme süreçleriyle belirlenen ana akım eğitim biçimleri ifade edilmektedir. 
ve raporların "bankacı eğitim” kavramı bağlamında eleştirel bir yaklaşımla yorumlanmasıyla hazırlanmıştır.

\section{Eleştirel Pedagojinin Kuramsal Temeli ve Bankacı Eğitim}

Eleştirel eğitim felsefesi olarak da adlandırılan eleştirel pedagoji; eğitimin varoluşsal ve toplumsal anlamını göz ardı ederek eğitim süreçlerini toplumun endüstriyel üretim süreçlerine entegrasyonun aracı olarak gören ve teknik-meslek edindirme odaklı bir bilgi anlayışına yaslanan modern eğitim yaklaşımlarının karşısında konumlanmış toplum öncelikli bir eğitim yaklaşımıdır. Aslan ve Kozikoğlu'nun (2015, s. 2) ifadesiyle "Sosyal, kültürel ve politik bir eşitlik" üzerine temellenmiş olan eleştirel pedagoji; "Bireyin özgürleşmesi gerektiğini savunan, bilginin diyalog ve sorgulama süreci sonucunda oluşması gerektiğine inanan ve eleştirel bilinç kazandırmaya yönelik bir eğitim anlayışını veya yaşam biçimini” ifade etmektedir.

Eleştirel pedagoji açısından her türlü eğitim etkinliği, bu felsefenin kurucu öncüleri arasında yer alan Paulo Freire’nin (1995, s. 16) belirttiği gibi "Ya öğrenciyi var olan duruma kaynaştırma ve bütünleştirme eylemi ya da mevcut durumu eleştirip dönüştürebilecek düşünsel olanakları öğrenciye sağlama etkinliği” olarak iş görür. Yani eğitim; mevcut haliyle toplumda var olan baskı ve hiyerarşi unsurlarını ihya etme ve yeniden kurma işlevini yerine getiren bir pratik iken; doğru uygulama ve müdahalelerle gündelik ve politik yaşamda özgürlük üreten bir niteliğe bürünebilir. Bu iki şıktan ikincisinin tercih edilmesi, eğitimi bir özgürleştirme pratiği haline getirecek çağdaş ve insancıl bir pedagoji için bir gerekliliktir. Bu bağlamda mevcut eğitim uygulamalarını insanı bilgi karşısında pasif bir alıcı konumuna indirgeyen "bankacı eğitim" kavramı ile betimleyen Freire (1970, s. 208); kendi yaklaşımını bankacı eğitimin antitezi olarak insan özgürlüğünü önceleyen aktif bir bilme ve anlama nosyonu etrafında şekillendirir.

Eleştirel pedagojinin anahtar kavramı niteliğindeki bankacı eğitim kavramı, öğrenciyi edilgen kılan tek yanlı bilgi aktarımına dayalı eğitim etkinliklerini ifade eden bir kavramdır (Yılmaz, 2016, s. 299). Eğitim olgusunu sosyal çevreyi adalet, eşitlik ve özgürlük lehine dönüștürmek için bilgi edinme, öz farkındalık kazanma ve kendini gerçekleştirme edimi olarak kabul eden eleştirel pedagoji açısından eğitimin amaçlarının gerçekleşmesinde en büyük engel bankacı eğitimdir. Freire’ye (1995, s. 60) göre öğrencilerin eğitim süreçlerine aktif katılımını engelleyen bankac1 eğitim, bu suretle onların yaratıcı ve dönüştürücü yetilerini körelterek edilgenleştirir. Eğitime yönelik eleştirilerde sıkça kullanılan "ezbercilik", "bilgi aktarımına dayalılık" ya da "öğretmen merkezlilik" gibi kavramlarla benzerlik göstermesine rağmen aslında tüm bu kavramların bir bileşkesi olarak adlandırılabilecek olan bankacı eğitim; bilginin depolanan bir meta, öğrencinin ise içi doldurulacak boş depo olarak görüldüğü eğitim süreçlerinin insanın eylemde bulunma ve dünyayı 
kendi sözcükleriyle adlandırma yetilerini iğdiş eden ve bu suretle onu insan olmaktan çıkaran bir baskı unsuruna dönüşmesini ifade etmektedir (Freire, 1995, ss. 67-68).

Bankacı eğitim bağlamında okul, sınıf, müfredat, öğretim programı, ders kitabı, öğretim materyali gibi eğitime dair tüm unsurlar toplumun egemen gruplarının öncelikleri lehine düzenlenir. Böylece bilgi depolama eylemi, toplumun geri kalanını egemenlik altına almak ve kontrol etmek için söz konusu baskın grupların hâkimiyetini geliştirmek ve devam ettirmek amacıyla yapılır. Eğitim faaliyetinin s1nıfta bilgiyi ve gücü uhdesinde bulunduran, ders anlatıc1 "özne" konumundaki bir öğretmen ve bu öğretmeni sabırla dinleyerek bilgilenen "nesne" niteliğindeki öğrenciler olmak üzere iki unsurdan oluşan bir olgu olarak tanımlandığı bankacı eğitimde öğretmenin görevi sadece öğrencilere bilgi verip onların kafasını doldurmak iken, öğrencilerin görevi de onları yazmak, ezberlemek ve gerektiğinde hiçbir şey ekleme ve çıkarma yapmadan tekrar etmekten ibaret olan edilgen tavırdır (Köylü, 2000, s. 242). Bankacı eğitimin tüm süreçleri öğrencinin dönüştürücü güdü ve potansiyellerini ortadan kaldırmaya, yani onu edilgenleştirmeye yönelik olarak işler. Öğrenciler, "kendilerine yüklenen yığma malzemeyi/bilgiyi istiflemekle ne kadar fazla meşgul olurlarsa; dünyaya bu dünyanın dönüştürücüleri olarak müdahale etmeleri durumunda oluşacak olan eleştirel bilinçleri de o kadar güdük kalacaktır" (Freire, 1995, s. 52). Bu durum eğitimi; bireyin varlığını, özgün algı kapasitesini ve kültürel geçmişini yok sayan, kişiliğini yozlaştıran, kararlılık ve iradesini felç eden bir faaliyete dönüştürme riskini beraberinde getirir.

\section{Din Eğitimi Açısından Bankacı Eğitim}

Bankacı eğitim kavramı, din eğitimi açısından öğrencilerin yaşantı ve deneyimlerinden soyutlanmış teorik bilginin, öğrenciler arası rekabete dayalı nicel ölçme-değerlendirme araçlarının ve teknik-meslekî kazanımların baskın durumda olduğu eğitim uygulamaları açısından anlam kazanmaktadır. Eğitimin ilk akla gelen hedefleri olan okuma, yazma ve bilgi edinmeye ilişkin kazanımları insana mahsus faaliyetler olarak vahyin en başında vurgulayan (el-Alak 96/1-5) Kur'ân-1 Kerim açısından bilmek ve anlamak gibi yetiler, insan olabilmenin koşulu olarak salt biliş yetisinin bir nesnesi değil, kişinin Tanrı, doğa ve diğer varlıklar karşısındaki konumunu belirleyen ontolojik bir belirteç niteliğindedir. Kılıç่in (1999, s. 211) vurguladığı gibi "Dindar olma ya da olmama durumu ancak din doğru bir şekilde anlaşıldıktan sonra irâdî, yani insanî bir tavır olarak ortaya çıkar". Bu doğru anlama, doğru bilgilenme ile gerçekleşir. Bu anlamda bilgi, kişilerin Aşkın Varlık karşısındaki konumlarını belirlemek için yargıda bulunmalarına imkân vermesi açısından bir hayli önem taşımaktadır.

Din eğitiminde özellikle Kurân, Sünnet, dua ve inanç gibi konuların öğreti- 
minde sıkça rastlanan ezbere ve bilgi aktarımına dayalı eğitim anlayışı, eleştirel pedagojideki bankacı eğitim kavramı bağlamında değerlendirilmesi gereken öncelikli konular arasında yer almaktadır. Öncelikle belirtmek gerekir ki; din eğitiminde, özellikle de belirli bir kutsal kitabı esas alan vahiy merkezli dinlerin eğitiminde ezberin bir öğretim metodu olarak kullanılması bir yere kadar zaruret olarak görülmelidir. İslam’ın temel kaynaklarının Kurân ve hadisler olması nedeniyle, Kurân harflerinin, tecvîd esas ve kaidelerinin, âyetlerin ve gerek Arapça gerekse ana dilde olmak üzere belli başlı sûre ve hadislerin ezberlenmesi doğaldır. Bu bakımdan eğitimde ezber; İslam'da Kur'ân'ın lafzen korunması, metinde yapılacak ekleme ve çıkarmaların önüne geçilmesi, hadislerin günümüze kadar muhafaza edilmesi ve ibadetlerin doğru bir şekilde yerine getirilebilmesi açısından zaruri bir yöntem olarak düşünülmüştür. Bireyin inandığı din hakkında bir kültür ve dünya görüşü geliştirebilmesi, dinî bir meseleyi anlayıp kavramaya ve o konuda hükümler çıkarmaya hazırlanması için mevcut bilgi birikimini genişletmesi kuşkusuz bir ihtiyaçtır. Bu gereksinim ezber yöntemini, tarih boyunca hemen hemen tüm İslam toplulukları için etkin bir öğretim yöntemi haline getirmiştir (bkz. Nazıroğlu, 2011, 229). Büyük ölçüde Kurân âyetlerinin ve hadislerin ezber yoluyla doğru bir şekilde öğretilmesine dayalı bir zemin üzerinde temellenmiş geleneksel din eğitimi anlayışı, Hz. Peygamber (s.a.v.) dönemindeki Suffầdan itibaren İslam din eğitimi kurumlarında devam etmiş, din eğitimi; âyetlerin, hadislerin ve İslam toplumunca önemli görülen dinî metinlerin öğrenci tarafından ezberlenmesi şeklinde gerçekleşmiştir. Daha sonra medreselerin şekillenmesi, İslam din eğitimin kurumsallaşması ve profesyonelleşmesiyle metnin hoca tarafından okunması ve açıklanması, açıklanan konunun öğrenciler tarafından not alınarak (imlâ) öğrenilmesi, soru-cevap, mütâlaa (anlayarak okuma), takrir, müzakere ve münazara gibi aktif yöntemler geliştirilmesine rağmen eğitimde bilginin ezberletilmesi, bir yöntem olarak günümüze kadar kullanılmıștır (Makdisi, 2018, ss. 168-170; Bilgin ve Selçuk, 2000, s. 3; Taşdemirci, 1989, s. 530).

Bu noktada; eleştirel pedagoji açısından, birçok yönden din eğitiminde öğrenmenin ilk adımı olması bağlamında eğitimsel bir gereklilik ve yöntem olarak görülebilecek ezberleme eyleminin bizatihi kendisinin değil, eğitimin ana karakteristiği haline gelmiş bir ezbercilik tavrının yargılandığını kaydetmek gerekir. Nitekim İslam hukuk ve eğitim tarihi konusunda önemli çalışmalara imza atmış şarkiyatçllardan George Makdisi de (2018, s.169) "İslâm eğitiminde ezberlemenin tamamıyla muhakeme dışı bir eylem olarak değil, zekâ ve kavrama ile desteklenen bir faaliyet" olarak anlaşıldığını ifade etmektedir. Bu noktadan hareketle dinî bilginin ezberletilmesini, not alınmasını ve bu suretle öğrenciye belletilmesini başlı başına bir problem olarak düşünmek insaflı bir değerlendirme olmayacaktır. Gür'ün de (2017, s. 20) dikkat çektiği gibi akıllıca seçilmiş konuların ezberlenmesi eğitimde bir gereklilik olarak görülebilir. Özellikle tümevarım, tümdengelim, çıkarsama ve sebep-sonuç ilişkilerini görme gibi akıl yürütme süreçlerinin doğru bir şekilde 
gerçekleştirilebilmesi için kişinin zihninde belirli bir bilgi birikiminin yapıland1rılması bir zarurettir. Bununla birlikte ezber yöntemi; anlama, sorgulama, yorumlama, çıkarım yapma, tartışma, mukayese etme, analiz-sentez gibi akıl yürütme süreçlerini dışarıda bırakarak körü körüne kabul etmeyi getirmesi halinde eğitim açısından olumsuz sonuçlar doğuracaktır (Kayretli ve Oral, 2014, s. 29). Ezberin bir yöntem olmaktan çıkarak ezberci eğitim anlayışına dönüşmesi anlamına gelen bu durum, din eğitimi süreçlerini bankacı eğitim kavramıla koşut bir şekilde otoritenin istediği doğrultuda evcilleşmiş ve ehlileşmiş, öz güveni zayıf ve kurallara sorgulamaksızın uyan insan prototipini yetiştirme iklimi haline getirecektir (Doğan, 2015, ss. 361-362).

İslam din eğitiminde böylesine önemli yer tutan ezberin bir yöntem olarak kullanılmasına karşı çıkan düşünür ve eğitimcilere rastlanmaktadır. Bunlar arasında yer alan İbn Haldun'un (2009, s. 778), eğitimde ezbere çokça yer verilmesini kişinin yorumlama ve ilimde derinlik kazanmasını zorlaştıran bir etken olarak gördüğü ve ezbercilik yerine uygulama, alıştırma, yorumlama, tartışma ve diyaloğu önerdiği de bilinmektedir. Bununla birlikte İbn Haldun'un eğitimde ezbere doğrudan karşı çıkmadığı, fakat ona gereğinden fazla ehemmiyet verilmesini yanlış bir uygulama olarak gördüğünü kaydetmek gerekir. Ezberin bir yöntem olarak kullanımı, ancak münazara, yorumlama, soru-cevap ve örnek olaylar üzerine pratik yapmak suretiyle ezberlenen içerik üzerine düşünmeye sevk edici uygulamalarla hedefine ulaşabilir. Bu bağlamda Fazlur Rahman da (1993, s. 266) ezberi "Yaratıcı ve müspet olmaktan ziyade edilgen ve alıcı bir öğrenme kültürünü doğuran” bir etken olarak zikretmektedir. Ona göre (1993, s. 266) “Tarihsel süreç içinde kayda geçirilmiş dinî yorumların dondurularak mutlaklık ve değişmez kaydı altında öğretilmesi, Müslüman zihni mumyalaştırarak onun yeni durumlar karşısında ya çözüm üretemez hale gelmesini ya da bu durumları görmezden gelerek kayıtsız kalmasını doğurmaktadır". Bu noktadan hareketle eğitime konu edilecek bilginin seçilmesinde ve işlenmesinde ezbere ve tekrara dayalı bir tutumun üretken olmaktan uzak, âtıl ve kendisi yaratmak yerine var olanı tüketen ve taklit eden zihinlerin şekillenmesine yol açacağı ifade edilebilir.

Ezbercilik ve bilgi aktarımına dayalı eğitim-öğretim süreçlerinin Freire’nin işaret ettiği bağlamda öğrenciyi tarih, toplum ve insanlık karşısında edilgen kılma faaliyetine indirgeyen sonuçları din eğitimi açısından da geçerlidir. Zihinleri alışılmış bilgilerle ve klişelerle doldurarak anlamaya, farkına varmaya, kendini gerçekleştirmeye ve sorumluluk almaya yönelik bilgiyi ihmal eden ya da kasıtlı olarak öteleyen din eğitimi uygulamaları; öğretmeyi standart bilgi aktarımı denklemi şeklinde düzenleyerek öğrencileri bu denklem içerisinde özerkliği elinden alınmış sürü nesneleri haline getirmeyi amaçlayan bankacı eğitim anlayışıyla örtüşür. Yalnızca önermeler düzeyinde bir bilgi aktarımı şeklinde işleyen bankacı nitelikteki uygulamalar; öğrencileri aktif hakikat arayışından uzaklaştırarak bilgiyi hazır ola- 
rak edinmeye alıştırmak suretiyle İslam din eğitiminin bireyi insan olma yolunda yetkinleştirme (insan-1 kâmil) vizyonunu sekteye uğratma tehlikesi taşımaktadır. Nurettin Topçu'nun ifadesiyle (1997, s. 158) "Bilginin isimler ve formüller halinde aktarılarak herhangi bir dünya görüşü oluşturulmaksızın ezberletildiği eğitim tarzı", eleştirel pedagoji açısından bakıldığında edilgenleşmeyi doğuran bir sürece dönüşme potansiyeli taşır. Öğrenciyi otoritenin bilgi yatırımı nesnesi haline getiren bu anlayışla bireylerin, Buber’in (2003, s. 93) belirttiği gibi varlığa katılmaktan, varlık ile olmaktan ve var olmaktan mahrum kılınarak insanın insan olmaktan alıkonulduğu bir sürece kapı aralanır.

İslâm’n bilme, anlama ve anlamlandırma gibi bilişsel yetilere hitap eden kavramsal içeriğinin öğrenilmesi, din eğitiminin en önemli aşamalarından birini oluşturur. Bu bakımdan din eğitimi kapsamında bilginin nasıl ve hangi bağlamda anlaşılması gerektiği büyük önem taşımaktadır. Mualla Selçuk’un (1998, s. 81) ifade ettiği gibi Kur'ân-1 Kerîm’de; bilginin kaynağı, nasıl bilgi edinileceği ve edinilen bilginin nasıl değerlendirileceğine ilişkin birçok uyarı ve ipucu mevcuttur. Örneğin Kurân'da "Senden önce de ancak kendilerine vahyettiğimiz kimseleri peygamber olarak gönderdik; eğer bilmiyorsanız kitaplar hakkında bilgi sahibi olanlara sorun" (el-Enbiyâ 21/7) âyetiyle bilginin iman ile olan ilişkisine dikkat çekilmiş; "Hakkında bilgin olmayan şeyin ardına düşme! Çünkü kulak, göz ve gönül, bunların hepsi ondan sorumludur" (el-İsrâ 17/36) âyetiyle de bilginin gerçekliği ve doğruluğuna dair bir farkındalık olarak ortaya konmuştur. İnsanın bilgilenme sürecine ilişkin olarak birçok âyette işaret edilen bu prensipler, din eğitiminde bilginin; bankacı eğitimde olduğu gibi aktarılıp ezberletilen ve sorgusuz sualsiz kabul ettirilecek bir veri paketçiği olarak anlaşılmaması gerektiği hakkında fikir vermektedir. Demek ki dinî bağlamda bilgi, günümüz eğitim anlayışlarında rastlanan; aktarılabilme, depolanabilme ve ezberletilebilme özelliklerine sahip bir mâlumat/enformasyon olmanın ötesinde, insanın varlık yapısı açısından anlamlı olan varoluşsal bir gerçekliğe işaret etmektedir.

Salt epistemik bir performans ve ussallık gayreti olmanın ötesine geçen bu tarz bir bilgi vizyonunun din eğitimi açısından bir referans çerçevesi olarak ele alınması, örgün ve yaygın din eğitiminin etkililik ve verimliliği açısından önemlidir. $\mathrm{Bu}$ açıdan başta öğretim programları olmak üzere ders kitaplarının ve öğretim materyallerinin; öğrenciye biliş-duyuş bütünlügü edindirecek kazanımlar bağlamında değerlendirilmesi gerektiği düşünülmektedir. Din Kültürü ve Ahlak Bilgisi (DKAB) dersinin öğretim programının (MEB, 2018a, 9) "Programın Uygulanmasına/Kitap Yazımına İlişkin İlke ve Açıklamalar” kısmında sûre ve duaların öğretiminde içeriğin ve mesajın kavranmasına yönelik vurgu yapılmış, öğrencilerin konularda ve ünite sonlarında geçen âyet, hadis, sûre ve duaları ezberlemeye zorlanamayacağ 1 ifade edilmiştir. Bununla birlikte DKAB dersinin genel amaçlarının belirtildiği bölümde (MEB, 2018a, 9) sıralanan 10 maddenin 6'sında "tanımak", 
"kavramak" ve "açıklamak" gibi bilişsel düzeye hitap eden amaçların yer aldığı; duyuşsal bağlamda değerlendirilebilecek amaçların yalnızca "saygı duymak", "içselleştirmek" ve "farkında olmak" gibi ifadelerle son derece sınırlı kaldığ 1 görülmektedir. Buradan hareketle dersin amaçlarının devinişsel ve uygulamaya yönelik beceriler noktasında son derece kısıtlı bir vizyona sahip olduğu söylenebilir. Çiçek'in (2019, s. 62) DKAB programını öğretmen görüşleri doğrultusunda değerlendirdiği çalışmasıyla da desteklenen bu durum bağlamında, programın amaçlarının bilgi eksenli olduğunu ve davranış kazandırmak açısından yetersiz kaldığını ileri sürmek mümkündür. Programın; sadelik ve anlaşılırlık adına öğretmen için ipucu teşkil edecek etkinlik örneklerini ve açıklamaları dışarıda bırakması, öğretmenleri dersi bilgi aktarımının ötesine taşıyarak bir duyuş ve uygulama edimi haline getirmesi hususunda ihtiyaç duyacağı ipuçlarından mahrum bırakmaktadır. Programda ayrıca "irdeler, değerlendirir, analiz eder, sorgular, tartışır, yorumlar" gibi üst düzey düşünmeye yönelik kazanımların az olduğu, kazanımların çoğunlukla “özetler, açıklar, tanır, söyler, sınıflandırır, eşleştirir, izah eder” gibi alt seviyedeki öğrenme durumlarına yönelik olduğu görülmektedir. Nitekim 2020 yılında Milli Eğitim Bakanlığı (MEB) Talim Terbiye Kurulu Başkanlığı tarafından yaptırılan araştırmada (MEB, 2020, s. 233); DKAB programında bilişsel, duyuşsal ve psikomotor alanlardaki kazanımlara makul düzeyde yer verilip verilmediğine ilişkin soruda öğretmenlerin \%42'si “orta düzeyde katılıorum", \%8'i ise "az katılıorum" ve "hiç katılmıyorum" yanıtını vermişlerdir. 2010 yılında hazırlanan bir önceki DKAB programına nazaran oldukça kompakt bir yapıda olduğu anlaşılan 2018 yılı DKAB programının, eleştirel pedagoji açısından anlam ifade eden duyuşsal ve devinişsel kazanımların nasıl edinileceğine ilişkin yöntem-teknik, etkinlik ve ders işleniş örnekleri bakımından yetersiz ve bu bağlamda net ve anlaşılır olmaktan uzak olduğunu belirtmek mümkündür.

Din eğitiminde bilgi aktarımı ve ezbere dayalı bir anlayış, yüksek din eğitimi açısından da sorun teşkil etmektedir (Akyürek, 2015, s. 381; Doğan, 2015, s. 358). İlahiyat fakültelerinde bilgi aktarma ağırlıklı bir eğitim verildiğine dikkat çeken Akyürek (2015, s. 381), bu durumun öğrencilerin "Dinî bilgiyi anlamak ve içselleştirmek yerine ezberlemelerine yol açtığını” vurgulamaktadır. Akpınar’ın (2007, s. 167) ilahiyat fakültelerindeki tefsir derslerine ilişkin yaptığı çalışmada da görüldüğü gibi ilahiyat öğrencilerinin büyük bir kısmı dersi ezberciliğe dayalı ve monoton bulduklarını ifade etmiş; "Kur’ân’ın mesajının günümüz insanına hitap edecek bir biçimde sunulamadığını, derslerin öğrenciye Kur’ân kültürü vermekten uzak olduğunu ve derslerde öğretilen ve ezberletilenlerin ise kısa zamanda unutulup gittiğini” vurgulamışlardır. Benzer bir sonuç Mehmedoğlu’nun (2000, s. 137) çalışmasında da ortaya çıkmış, araştırma kapsamındaki ilahiyat öğrencileri Kur'ân derslerinin ezbere dayalı olmak yerine Kur'ân’n anlaşılmasına vesile olacak bir süreç olarak düzenlenmesini talep etmişlerdir. İlahiyat öğrencilerinin Kur'ân okuma ve tecvid derslerinin işlenişi hakkındaki kanaatlerinin incelendiği bir başka 
araştırmada ise hem hoca hem de öğrenci açısından basit ve rahat uygulanabilir olduğu için ezber ağırlıklı bir çalışma programının uygulandığı, gerekli ezberlerin yapılmış olması ve öğrencinin ezberini sorunsuz bir şekilde okumasının derste yegâne başarı kriteri olduğu ifade edilmiştir (Şenat, 2016, 227). Eleştirel pedagojinin bankacı eğitim kavramını çağrıştıran bu sonuçlar, din eğitiminde öğrenilen dinî bilgiyi içselleştirme, zihnin çeşitli katmanlarında değerlendirme ve karakterle bütünleştirerek bir ahlak ve ruh zenginliği halinde hayata yansıtmaya yönelik kazanımların inkıtaa uğradığını akla getirmektedir. Eğitimin salt entelektüel bir etkinlik olmanın ötesine geçemediği bu eğitim durumlarıyla bilgi, gerçeklikle ilgisiz, içinde yaşadığımız dünya ve hayatın bütünlüğüyle bağlantısı kopmuş içeriklerden ibaret kalmakta ve Cohen'in (1979, s. 98) "Varoluşun organik bir parçası" olarak ifade ettiği ontolojik bir unsur haline gelememektedir. Bu sürecin varacağ1 yer, din eğitimi açısından öğrencinin Allah tarafından kendisine bağışlanmış dönüştürücü ve oluşturucu yeteneklerinin farkına varamaması, kendi bilincine ermemesi ve nihayet kendisine yabancılaşmasıdır.

\subsection{Nesnel Bilgi Odaklılık}

Din eğitiminde bankacı eğitimin en belirgin tezahürü, dinî bilginin insan yaşantılarından ve deneyimlerinden kopuk birtakım önermeler ve bilgi paketçikleri halinde öğretilmesidir. Bu durum dinî bilginin, sadece biliş yetisinin nesnesi haline getirilmesi ve dinle ilgili her kavramın "açıklayıcı ve öğretici” etkinliklerden ibaret didaktik bir eğitim tavrıyla öğretilmesi şeklinde gerçekleşmektedir. Çok boyutlu bir olgu olan din olgusunu nesnellik ve bilimsellik kaygısı adına "Ölçülen, değerlendirilen, girdileri ve çıktıları olan bir müfredat nesnesi” (Hussien, 2006, s. 213) haline getirmekle kendini gösteren bu eğitim tavrı; din eğitimini, salt bilişsel alana hitap eden kitâbi bilgiye dayalı kavramsal içeriklerin aşırılaştırıldığ bir sürece dönüştürür. Bu durum; Rahath ve Hashim’in (2013, s. 29) belirttiği gibi “Öğrencilerin varoluşsal deneyimlerine yabancı ve içinde yaşadığımız dünya ile ilişkilendirilmekten uzak içerikler üzerinde uzun uzadıya açıklamalar yapmayı önceleyen” bir din eğitimine kapı aralayacaktır.

Din olgusunun felsefe, tarih, psikoloji ve eğitim bilimleri gibi disiplinlerin akademik yönelimine hitap eden; teori ve kavramlarla açıklanabilir boyutu, hiç kuşkusuz dinin bizatihi bilimsel anlayışa indirgenebileceği anlamına gelmez. Bu anlamda akademik ilginin nesnesi olan din ile pratik yaşantılarla deneyimlenen dinin insan açısından bambaşka şeyler ifade edebileceği gözden kaçırılmamalıdır. Nesneleri ve olguları adlandırmanın aracı olan sözcüklerin ve kavramların, insan ruhunda eylem ve deneyimlerle gerçekleşen ve görünür hale gelen dinî gerçekliği yansıtacağını düşünmek, dinin anlam ve hakikatini daraltmak anlamına gelecektir. Buber'in (2003, s. 55) ifadesiyle "Bizimle karşılaşan, bekleyen ve varlı̆̆ devam eden şey, bilimin nesnesi olduğunda hareketsiz kalan, duran, koparılan, sertleșen, 
göze çarpan, ilişkiden ve varlıktan mahrum bir şey haline gelir". İman, namaz, duâ, tövbe, Kurân, vahiy, rahmet, sadaka vb. dinî kavram ve konuların hakikatte birer gösterim ya da sembolden ibaret olan sözcüklere indirgenerek öğretilmesi; tüm bunların ibadetler ve dinî pratikler yoluyla doğrudan ve dolaysızca yaşanmasıyla gerçekleşecek dindarlık tecrübesinin önüne geçme riski taşımaktadır.

İslam din eğitiminde "değer hükümsüz, sırf nesnel bilginin imkânsızlığını" vurgulayan Bilgin (2001, s. 48), nesnellik ve bilimsellik çabasının bazı durumlarda "kontrolsüz etkilenmelere, istenmedik davranışlara ve başıboşluğa yol açabileceğini” belirtmektedir. Zira bilgi, modern eğitim yaklaşımlarının öngördüğü bağlamda nesnellik iddiasına yönelik bir yanılgıyla değerlerden ve öznel olandan arındırıldığında; yalnızca "olan şeye" odaklanarak "olması gerekeni” gözden kaçırır. Nesnel bilgiye yönelik aşırı vurgu; matematik, fen bilimleri ve sosyal bilimler gibi alanların eğitiminde kabul edilebilir bir duyarlılık olmakla beraber; din ve ahlak gibi konuların eğitimine ilişkin süreçlerin etkisizleşmesine ve verimsizleşmesine yol açabilir. Yaşantı ve deneyim yüklü bir bilgi türü olarak dinî bilgi; kişinin vicdanında, onun eylem, gereksinim ve beklentileriyle vücûda gelir ve olgunlaşır.

İslâm’da bilgi, Kilıç’in (2003, s. 157) ifadesiyle "Reel dünyada anlama, yorumlama ve uygulama süreçleriyle ortaya çıkarak var olur". Yani dinî alanda bilme, anlama, öğrenme ve yorumlama gibi süreçler yalnızca epistemik değil, insanın varoluşuna yönelik bütüncül bir ilgiyi gerektiren ontik bir nitelik de taşımaktadır. Bilgiyi ve bilme ediminin önemi bağlamında Hz. Âdem (a.s.) kıssasını (el-Bakara 2/30-40) örnek gösteren Fazlur Rahman (2011, s. 449); “Âdem'in melekler ve diğer yaratılmışlarda olmayan yaratıcı bilgiye sahip olduğunu ve bilgiyi keşfetme kapasitesiyle donatıldığını" ifade ederek insanın bu ayrıcalıklı konumunun ve sorumluluğunun bilme yeteneğinden geldiğini ileri sürmektedir. Eğitimde bilgi, bu bağlamda Roberts'in (1996, s. 153) ifadesiyle "nötr, tarafsız, değerden ve duygulardan arınmış bir şey olarak değil; duygularla, deneyimlerle, duyumsamayla sıkı sıkıya bağlı olan varoluşsal bir süreç" olarak düşünülmelidir. Dinî bilginin aktarılması, bilinmesi ve anlaşılması gibi epistemik süreçler; hem dinî tutum ve dinî alışkanlık kazanma, hem de dindarlık gibi günlük hayatla ve duygularla ilintili, doğrudan deneyim yüklü olgular şeklinde yaşamın her alanında ve evresinde karşımıza çıkmaktadır.

Bankacı eğitimin nesnel bilgi odaklı eğitim anlayışının mevcut din eğitimi uygulamalarındaki tezahürleri özellikle yüksek din eğitiminde dikkat çekmektedir. Bu bağlamda 1949 tarihinde Ankara Üniversitesi İlahiyat Fakültesi’nin kuruluş sürecinde yapılan tartışmalara bakıldığında; yüksek din öğretimini dinî alanı bilimsel ve akademik anlamda özümseme, dinî konularda nitelikli düşünebilme, bilgi üretebilme ve üretilen bu bilgiyi yorumlama, sınıflandırma ve analiz etmeye dayalı bir bilimsel uzmanlık nosyonu çerçevesinde şekillendirmeye yönelik bir arayış sezilmektedir (Baltacıoğlu, 1949, s. 278). Din eğitiminde nesnel ve bilimsel 
ölçütlere uygun bilgi arayışına yönelik böylesi bir hassasiyetin, din olgusunu ve din eğitimini rasyonel, tutarlı ve hesabı verilebilir evrensel bilginin üretilip dolaşıma sokulduğu bilimsel bir etkinlik alanı haline getirme gayretlerinden kaynaklandığı anlaşılmaktadır. Bu bağlamda Türkiye'de yüksek din öğretiminin; çağın pozitif ilimler merkezli bakış açısına uygun bir şekilde planlandığ 1 ve dinî gerçekliğin mahallî ihtiyaçlar da göz önünde bulundurularak nesnel bir bakış açısıyla ele almaya yönelik bir gayretle programlandığı görülmektedir. Modern çağın aklı ön plana çıkaran ve rasyonel aklın ürettiği mantık normlarına ve dış dünya hakkındaki duyu verilerine dayanan epistemolojisini dinî alana uyarlamaya yönelik bu bakış açısı, dinin özünde var olan tecrübeye ve eyleme dayalılık boyutunu ikinci plana atarak bilgi boyutunu ön plana çıkarma eğilimindedir.

Elbette ki yüksek din öğretiminde, epistemolojik tutarlılık ve geçerlilik şartlarını haiz doğru bilgi üretimine yönelik bilimsel, teorik ve analitik bir hassasiyetin büsbütün gereksiz olduğu iddia edilemez. İlahiyat fakülteleri, yaygın din eğitiminden farklı olarak mezunlarını din alanında profesyonel düzeyde bilgi üretecek ve halka rehber olacak uzmanları yetiştiren kurumlardır. Bu görev, ilahiyat fakülteleri bünyesinde din olgusunun bilimsel ve akademik düzeyde ele alıp tartışılmasını gerekli, hatta kaçınılmaz hale getirmektedir. Bununla birlikte ilahiyat alanını yalnızca akademik anlamda bir bilgi üretim ve araştırma merkezi olmakla sınırlamak ve dinin pratik, tecrübî ve duyuşsal boyutlarını görmezden gelmek; İslam’ın kurtarıcı ve gerek enfüsî gerekse âfâki anlamda bireyi ve toplumu özgürleştirmeye yönelik vizyonunu daraltacaktır. Öğrencinin hayatına dokunmayan, mevcut dinî yaşantılarını görmezden gelen ve onu yeni deneyimlerle karşılaştırmayan bir bilgi anlayışına dayalı din öğretimi faaliyetleri; din olgusunun güncel sorunlar düzleminde ortaya çıkan değerini gözden kaçırarak eleştirel pedagojinin bankacı eğitim olarak adlandırdığı bireysel, toplumsal ve küresel sorunlara karşı yabancı, hayattan kopuk ve kısıtlayıcı eğitim durumlarının gerçekleşmesine sebebiyet verecektir. Bu bağlamda mevcut ilahiyat eğitiminin teoriye ve tarihe hapsolmuş karakterinin ilahiyatçıları dinî hizmetler, eleştiri ve otoriteye karşı duruş gibi hususlarda klasik İslam âlimi tipolojisinin bile gerisine düşürdüğü söylenebilir (bkz. Nazıroğlu, 2020, s. 255). Zira dini, nesnel bağlamda bir bilimsel disiplin olarak öğrenme ve öğretmeye yönelik çaba ve gayretler; objektiflik ve tarafsızlık adına dinin özünde var olan ancak salt zihinsel ve mantıksal süreçlerle kavranamayan sevgi, samimiyet, gönüllük, özgecilik, manevî heyecan, cehd ve gayret gibi duyuşsal unsurları deneyimden uzak tutarak örtbas etmektedir. Bu durum din olgusunu hem öğrencinin hem de eğitimcinin gözünde bir mânevî olgunlaşma ve dünya- ahiret kurtuluşunun vesilesi olmaktan çıkarma riski taşımaktadır. Bu yüzden din eğitimi kapsamında öğretilecek içeriklerin psikoloji, sosyoloji, gelişim psikolojisi ve eğitim bilimleri gibi disiplinlerin filtresinden geçirilerek 1slah edilmiş ve standardizasyona tabi tutulmuş dinî içeriklerle sınırlı kalmaması ve din eğitimi süreçlerinde yerel, kişisel ve tekil tecrübelerin de dikkate alınması gerektiği düşünülmektedir. 
Örgün eğitimde nesnel bilgi yönelimine ilişkin problemli denebilecek vurguların ilkokul ve ortaokul DKAB dersi programında da yer aldığı görülmektedir. DKAB dersinin 2018 yllında hazırlanan İlkokul (4. Sinıf), Ortaokul (5, 6, 7 ve 8. Sinıflar) ve Ortaöğretim $(9,10,11$ ve 12 . Sinıflar) programının Temel Felsefe ve Genel Amaçlar bölümünde açılanan (MEB, 2018a, 2018b, s. 8); "İslam dininin (ve diğer dinlerin) betimleyici bir yaklaşımla öğretime konu edilmesine" yönelik amaç; yukarıda açıklamaya çalıştığımız din eğitiminde objektif bilgiye yönelik kaygının bir tezahürü olarak görülebilir. Programın Uygulanmasına/Kitap Yazımına İlişkin İlke ve Amaçlar arasında yer alan "Gerek farklı din ve inançların öğretiminde gerekse İslam düşüncesinde ortaya çıkan yorumların öğretiminde olgusal bir yaklaşım benimsenir" ilkesi de (MEB, 2018a, 2018b, s. 9) değer hükümlerini ve yaşantıları saf dışı bırakan evrenselci bilgi yöneliminin bir yansıması olarak anlaşlmaya müsaittir. Zira din eğitiminde herhangi bir dinin içinden ve o dinin bakış açısıyla yapılan bir eğitimin, o din odaklı olması kaçınılmazdır. Aksi durumda din eğitimi bir dinler tarihi, din felsefesi yahut din fenomenolojisi dersine dönüşür. Bu noktada 2018 yılı programındaki olgusal ve betimleyici bakış açısına yönelik vurguların, DKAB dersinin 2010 yılında hazırlanmış bir önceki programında yer almadığına dikkat çekmek gerekir. Bunun sebebi, 2010 yılı programının bilgiyi dışarıdan aktarılan bir şey değil de öğrencinin zihninde yapılandırılan ve öğrenme olgusunu, "öğrenmeyi öğrenme" olarak formüle eden yapılandırmacı paradigmanın etkisinde hazırlanmış olmasında aranabilir (Yapılandırmacı yaklaşımın din eğitimiyle ilişkisi hakkında ayrıntılı bilgi için bkz. Okumuşlar, 2014; Kaymakcan, 2012; Zengin, 2010). Bu açıdan öğrenciyi öz yaşantıları ve sosyal çevresiyle bütün halinde ele alan bir pedagojik mimariye sahip yapılandırmacı eğitim anlayışının; din olgusunun insan benliğini gerçekleştirmedeki potansiyelini işletmek açısından nesnel bilgi yönelimli pozitivist paradigmaya göre daha işlevsel olduğu ileri sürülebilir.

\subsection{Rekabet ve Sıralamaya Dayalı Ölçme ve Değerlendirme Anlayışı}

Bankacı eğitimin din eğitimindeki bir başka tezahürü, modern dönemdeki geniş çaplı okullaşma süreci, öğrenci sayısındaki hızlı artış ve uzaktan eğitim olanaklarının gelişmesine bağlı olarak yaygınlaşan standart ölçme ve değerlendirme mantalitesidir. Eğitimin temel öğeleri arasında yer alan ölçme ve değerlendirme, özellikle öğrencinin edilgen ve alıcı konumunda olduğu öğretmen merkezli eğitim yaklaşımlarında eğitim sürecinin bir ürünü olarak görülen makbul öğrenci tipini çok sayıda öğrenci arasından olabildiğince az maliyetle ve kısa sürede eleme işlevini yerine getirmektedir. Modernizm etkisindeki yarışmacı ve rekabetçi dünya görüşlerinden doğan bu ölçme ve değerlendirme anlayışı, öğrenmeyi bir ürün ve çıktı olarak değerlendirmesi, bilginin uygulanmasından çok anımsanmasına yönelik olması ve tek bir doğru yanıta odaklanması gibi özellikleriyle ön plana çıkmaktadır (Alaz ve Yarar, 2009, s. 5). 
Pozitivizmin nesnel bilgi yönelimli doğasını yansıtan modern ölçme ve değerlendirme anlayışı, her bireyden aynı doğru yanıtı beklemek suretiyle müfredat aracılığıyla dayatılan standartlaşma ve aynılaşmayı gerçekleştirme görevini yerine getirir. Berberoğlu'nun $(2006,116)$ ifadesiyle "Algoritmik hesaplama (işlem yapma), ezber bilgi, derinliği olmadan çok fazla kavram ve prensibi öğrenme ve yazılı materyaldeki bilgileri aynen aktarma gibi öğrenme çıktılarını ölçmeye dayalı” bu sınav mantığı, insanı kendi öznelliği ve eşsizliği içerisinde kavramaktan uzaktır. Standart normal dağılım içerisinde kümelenmiş çoğunluğun ortalama değerini belirlemeye dayalı bir anlayış içerisinde; insanın biricikliğinin yansıması olan bireysellik ve özgünlük gibi özellikler, normun uzağında ya da normal dışı olarak belirlenerek başarısız olarak kodlanır ve standart olan, başarı olarak kaydedilir. Memon ve Ahmad'in (2006, s. 3) "Yönetici bakış açısı" olarak adlandırdığı bu tahakkümcü ve totaliter tavır; öğrenciyi ödül ya da cezaya dönüşebilen not unsuruyla koşullandırarak, onun, öğretmen-otorite tarafından verilecek nicel bir değeri bilgi ve niteliğin önündeymiş gibi algılamasına yol açacaktır. Sınav ve başarı odaklı olmayan öğrenmelerin anlamsız ve gereksiz olarak anlaşılması sonucunu doğurabilecek bu tutumun aynı zamanda; dinî gerçekliği salt bilişsel yetilere hitap eden taraflarıyla ön plana çıkarttığı ve duyuşsal, devinişsel, sosyal ve manevî yönleri ihmal ettiği söylenebilir (Gümüş, 2018, 9). Din eğitimin en can alıcı boyutlarını oluşturan bu hususların ihmali, öğrencilerin derse karşı ilgi göstermesini ve olumlu tutum geliştirmesini yavaşlatacağından, dersin başarısını ve öğrenmeyi de etkileyebilecek niteliktedir.

Bireyleri piyasanın ihtiyaç duyduğu üretici ve tüketici davranışlarına alıştırma hedefini eğitimin temel hedefi olarak benimsemiş çağdaş yaklaşımların karakteristik tezahürü olan standart ölçme ve değerlendirme araçları, din eğitimi bağlamında bireyi norm haline getirilmiş davranış ve alışkanlık şemalarına mahkûm etmeye, benzer davranış örüntüleri etrafında aynılaştırmaya ve bu suretle sorgulama yetisini törpülemeye yönelik bir tutuma da kapı aralamaktadır. Öğrenciyi; Allah vergisi yeteneklerini, hayal kurma kapasitesini ve geleceğe yönelik umutlarını birtakım standart başarı kriterlerine uyarlama ve nicel verilerle ifade edilen rakamsal notlara tahvil etme mecburiyetiyle baş başa bırakan bir ölçme-değerlendirme mantığı içerisinde din eğitimi, tam da bankacı eğitim kavramıyla açıklanabilecek bir bağlamda kitleleri standart tepkiler veren birer robot haline getirmeye yönelik edilgenleştirici bir eğitim paradigmasının uygulama alanı haline gelmektedir. Önceden belirlenmiş bilgi, beceri ve davranışları ölçmeye dayalı bu anlayış; bireyin ezberlediği hazır bilgiye yoğunlaşarak onun özgün varoluşu hakkında suskun ve kör kalırken, bireyin bilinç ve yaşam dünyasını Habermas’ın (2001, s. 807) kavramıyla "kolonizasyona" uğratır. Dahası bireye belirli bilgi ve davranış kalıplarını dayatmak suretiyle, onu isimden ve sûretten mahkûm anonim ve tekdüze bir varoluşa hapseder. Bu açıdan modern ölçme ve değerlendirme anlayışının bireyleri tartılabilen, ölçülebilen ve kıyaslanabilen varlıklar olarak gördüğ̈u ve Foucault’nun 
(1992, s. 237) deyimiyle "Bireysel çizgileri türdeş hale getirme" işlevini yerine getirdiği söylenebilir.

Yüksek din eğitiminde ölçme ve değerlendirme süreçlerinin durumu bağlamında Akyürek (2015, s. 382), sınavların malumat düzeyindeki bilgileri ölçmeye yönelik ve bilgi aktarımına hizmet eder yapıda olduğunu ifade etmektedir. Korkmaz da (2018, s. 377) ilahiyat fakültelerinin sorunlarını sıralarken fakültelerdeki öğrenci sayısının artmasıyla hocaların öğrencilerin ezber bilgisini ölçen test sınavlarına yoğunlaştığını, bunun yerine "Öğrencilerin fakültede kazandıkları zihinsel, dilsel, akademik vb. becerileri ölçecek, görüp, geliştirecek bir eğitim ve ölçme anlayışına geçilmesine ihtiyaç duyulduğunu" ifade etmektedir. Yüksek din eğitimindeki ölçme ve değerlendirme sorununun temelinde öğretim elemanlarının formasyon eksikliği kadar; özellikle 2010’lu yıllarda birçok ilde ve üniversitede açılan ilahiyat fakültelerinin öğrenci sayısındaki hızlı artışın yattığı söylenebilir.

DKAB derslerinde ölçme ve değerlendirmenin durumu bağlamında Çakmak'ın (2011, ss. 174-175) DKAB öğretmenleri arasında yaptığı araştırmanın sonuçları çarpıcıdır. Bu çalışmada DKAB öğretmenlerinin boşluk doldurma, çoktan seçmeli test ve eşleştirme soruları gibi geleneksel teknikleri; performans ve proje ödevi, öz değerlendirme ve sözlü sunum gibi tamamlayıcı araçlara göre daha sık kullandıkları ortaya çıkmıştır (Geleneksel ve tamamlayıcı ölçme-değerlendirme yöntemleri hakkında bkz. Bahar vd., 2014). Söz konusu araştırmalarda geleneksel sınav yöntemlerinin daha fazla kullanılmasının gerekçeleri; hazırlama kolaylığı, okuma ve puanlama basitliği, ders sürelerinin yetersizliği ve alternatif yöntemlerin kalabalık sınıflarda uygulanmasındaki zorluk olarak belirtilmiştir (Karbeyaz, 2018, 77; Çakmak, 2011, 177; Ulu, 2011, 75). Öte yandan Karbeyaz’ın (2018, s. 92) yaptığ1 araştırmada öğretmenlerin, DKAB dersinde öğrencilerin not kaygısı yaşamalarını ders adına bir problem olarak gördükleri tespit edilmiştir. Bu bağlamda ülkemizde 2013 yılından itibaren ulusal ölçekte yapılan lise ve üniversiteye giriş sınavlarına DKAB dersinden soruların sorulmaya başlanması da dinî alanın, teknik bir bağlama yerleşerek girdi-çıktıları olan bir müfredat nesnesi ve öğrencilerin birbirleriyle yarışacağı bir alan olarak algılanmasına sebebiyet verebilecek niteliktedir. Memon ve Ahmad'ın (2006, s. 8) belirttiği gibi din eğitiminde "niceliğe dayalı ve sonuç merkezli” bir anlayışı getirecek olan bu durum, din olgusunun özellikle ortaokul ve lise öğrencileri arasında çoktan seçmeli bir sınav görevi şeklinde algılanma ihtimalini doğurmaktadır.

MEB (2017, ss. 14-16) tarafından 2017 yılında hazırlanmış “Öğretmenlik Mesleği Genel Yeterlikleri’ başlıklı kitapçıkta yer alan "meslekî beceri yeterlik alanı” göstergeleri arasındaki "Öğrencilerin bireysel farklılıklarını ve sosyokültürel özelliklerini dikkate alarak esnek öğretim planları hazırlar” maddesi ile “Tutum ve Değerler Yeterlik Alanı" göstergeleri arasında bulunan "Her öğrenciye insan ve birey 
olarak değer verir" maddesi; eleştirel pedagojinin standartlaştırmaya karşı bireyselliği ve özgünlüğü teşvik eden ölçme-değerlendirme perspektifiyle paralellik arz eden ifadeler olarak anlaşılabilir. Ayrıca 2018 yılında güncellenen ilkokul, ortaokul ve ortaöğretim DKAB öğretim programlarında geçen şu tümceler de Türkiye'de ilköğretim ve ortaöğretim din derslerinin program hazırlayıcılarının teorik düzeyde de olsa rekabet ve sıralamaya dayalı ölçme ve değerlendirme araçlarının olumsuzluklarının farkında olduğunu göstermektedir (MEB, 2018a, 2018b, s. 5):

"Hiçbir insan bir başkasının birebir aynısı değildir. Bu nedenle öğretim programlarının ve buna bağlı olarak ölçme ve değerlendirme sürecinin "herkese uygun", "herkes için geçerli ve standart olması" insanın doğasına terstir. Bu sebeple ölçme ve değerlendirme sürecinde azami çeşitlilik ve esneklik anlayışıyla hareket edilmesi şarttır."

Din eğitimi açısından dikkate alınması gereken bu ifadeler, öğrencinin birikim ve kazanımlarını nicel birimler halinde verileştirerek istatistiksel ölçümün nesnesi haline getiren, onun yaratıcı yeteneklerini yok sayarak özgürlük yitimine uğratan modern eğitim anlayışlarının olumsuz etkilerine nasıl karşı konulacağına dair bir ipucu niteliğindedir. Bu bağlamda bankacı eğitimin öğrenciyi notla ödüllendirme/ cezalandırma mantığına dayalı sınav anlayışından uzaklaşılması ve bireye eşref-i mahlûkat konumunu hatırlatacak şekilde bireysellik, özgünlük, yaratıcılık, diyalog ve eylem temelli ölçme yaklaşımlarının geliştirilmesi bir ihtiyaç olarak karşımıza çıkmaktadır.

\subsection{Teknik ve Meslekî Bilginin Egemenliği}

Eğitimin günümüzde büyük ölçüde kalkınmacı ve işletmeci hedeflere odaklandığına ve piyasanın ihtiyaç duyduğu üreten/tüketen insanı yetiştirmeyi öncelediğine dikkat çeken eleştirel pedagoji, modern eğitimin bu işgücü yetiştirme görevini teknik ve araçsal bilgiyi yaygınlaştırmak suretiyle gerçekleştirdiğini ileri sürmektedir. Bankacı eğitimin belirgin özelliklerinden biri olan bu tutum, eğitimin diğer alanları gibi din eğitimi alanını da öğrencinin kendi iç dünyasını, öznelliğini ve insanlığını keşfettirecek bir süreç olmaktan çıkararak meslek edinmenin bir aracı haline getirmektedir.

Din eğitiminde teknik ve meslekî bilgi odaklı bakış açısının en fazla tehdit ettiği alanın yüksek din öğretimi olduğu söylenebilir. Bu bağlamda Altaş (2018, s. 230); günümüzde ilahiyat fakültelerinin "cami mihrabı, kürsüsü, müftülük makamı, öğretmenlik becerileri veya Kurân kursu öğreticiliği yeterlilikleri açısından değerlendirildiğini” ileri sürmekte ve bu kurumların “iyi Kur'ân okuyan mezunlar vermemekle ve vaaz edebilecek nitelikte elemanlar yetiştirememekle sorumlu tutulduklarını" ifade etmektedir. Altaş'ın bu tespitini destekleyen Yapıcı da (2015, 
s. 79) bu bağlamda 2013 yılında YÖK Genel Kurulunca kabul edilen ve müfredatta felsefe derslerinin ağırlı̆̆ının azaltılmasını öngören ilahiyat programında yetiştirilmesi amaçlanan ilahiyatçı tipolojisinin "Sadece ve basitçe vaaz edip namaz kıldırabilen, Arapça ibare okuyabilen kişiler” olduğunu ifade etmektedir. İlahiyat fakültelerine biçilen rolün; siyasî otoritenin belirlediği din, eğitim ve kültür politikalarını halka gereği gibi, eksiksiz ve kendinden bir şey katmadan arz etmekten sorumlu personel ve teknisyen yetiştirmek olduğuna dair kanaat uyandıran bu durum, büyük ölçüde modern üniversite anlayışının yüksek öğretimi profesyonel bilgi ve becerileri vermekle görevli bir meslek edindirme kurumu olmaktan ibaret gören tutumundan kaynaklanmaktadır.

Eski Yunan'dan bu yana bilgelik ve hikmet kaynağı olarak görülen akademi fikrinden, ulus devletin ve ulus devlete bağlı piyasa endüstrisinin çarklarını döndürecek eleman yetiştirme fabrikasına doğru bir savrulmayı ifade eden bu eksen kayması, eğitimin her alanında olduğu gibi din eğitimi alanını da iyiden iyiye teknik bir bağlama oturtarak mekanikleştirmekte ve din eğitimini sevgi, empati, gönüllülük ve amatör bir ruh gerektiren doğasından kopararak istatistiksel ve deneysel araştırma süreçleri aracılığıyla "daha profesyonel eğitici", "daha iyi müfredat", "daha etkili öğretim yöntem-teknikleri” ve "daha doğru sonuç veren ölçme-değerlendirme araçları” geliştirmeye dayalı bir üretim etkinliği haline gelme riskiyle karşı karşıya bırakmaktadır. Altaş (2015, s. 387), ilahiyat fakültelerinin karşı karşıya olduğu bu durum bağlamında "Neyin iyi olduğuna, neyi bilmesi gerektiğine, nasıl düşüneceğine, neyin dindarlık olacağına” küresel sermaye çıkarları doğrultusunda karar verildiğini ifade etmektedir.

Türkiyede yüksek din öğretiminin tek tip bir sosyal mühendislik projesi olarak teknik ve meslekî bir bağlamda anlaşıldığına dair diğer bir gösterge, uzaktan ilahiyat eğitimi verilen İLİTAM (İlahiyat Lisans Tamamlama) programlarının sayısındaki anormal artıştır (Bayraktutan, 2021, ss. 41-42). Öğrenilen içeriğin sadece çoktan seçmeli sınavlarla ölçüldüğü, hocaların öğrenciye rehberlik etme ve öğrenci ile diyalog kurma imkânlarının son derece kısıtlı olduğu dijital öğrenme ortamlarına dayalı olan bu programların, bireylere öğrendikleri bilgiyi dinî alan ile sağlıklı bir ilişki inşa etme, dinsel anlam evreni karşısındaki duruş belirleme, kendi dindarlığını kurma ve bu formasyon ile toplumun karşılaştığı teolojik ve sosyal problemlere çözümler üretme adına ne derece faydalı olduğu tartışma konusu bile yapılmamıştır. İLİTAM üzerine yapılan tartışmalarda bu programların öğrenci ile din arasında varoluşsal bir irtibat kurmadaki işlevi konu edinilmemekte; ağırlıklı olarak hocalarla yüz yüze iletişim kurma imkânının, Arapça ve Kurân-1 Kerim derslerinin, vaaz ve hutbe hazırlama konusundaki yetkinliklerin ve sûre-dua öğretim tekniklerinin uzaktan eğitim araç-gereçleriyle verilmesindeki zorluklara dikkat çekilmektedir (bkz. Altaş, 2018, ss. 231-232; Kılınç, 2015; Dağ, 2013; Bayraktar, 2010). Din hizmetlerinin usûlüne uygun bir şekilde deruhte edilebilmesi için 
kuşkusuz gerekli ve kendi içinde son derece değerli olan bu beceri ve yetkinlikler; hayatın gerçek problemlerinden uzak kalmaları ve bağlamlarından soyutlanarak ögretilmeleri halinde insanı tarih ve toplum karşısında özne kılmaktan ve insan varoluşuna bir şey katmaktan uzak teknik birer bilgi olmaktan ibaret kalacaklardır.

Eleştirel pedagojinin bankacı eğitim kavramını akla getiren bu durumun büyük ölçüde; din hakkında konuşmanın, görüş bildirmenin ve liderlikte bulunmanın ölçülebilir ve sınanabilir birtakım yeterlilik kriterlerini yerine getirmekle ulaşılabilecek birer meslekî nitelik olarak anlaşılmasından kaynaklandığını ileri sürmek mümkündür. Din eğitiminin salt teknik ve meslekî bir düzlemde değerlendirilir hale geldiği ve ferdî, sosyal, kültürel, toplumsal ve küresel sorunlar bağlamındaki önem ve değerine ilişkin soruların ihmal edildiği bu profesyonelleşme sürecinin, özellikle 2010 sonrası dönemde yaygın ve örgün din eğitimcisi istihdamındaki niceliksel artışın ilahiyat fakültelerini ve imam-hatip okullarını kolay yoldan meslek edinme mecrası haline getirmesiyle ilintili olduğu düşünülebilir. Son yıllarda her şehirde, hatta her üniversitede açılan İlahiyat/İslâmî İlimler fakülteleri, doğal olarak bu fakültelere öğrenci alımında gözle görülür bir kontenjan artışına yol açmış, 2020-2021 eğitim-öğretim yılı itibarıly yeni kayıt olanlarla birlikte bu okullarda ön lisans ve lisans düzeyinde 350 bini aşkın öğrenci öğrenim görür hale gelmiştir (bkz. YÖK, 2021). İmam-hatip okullarının ve genel eğitim kapsamında faaliyet gösteren okulların müfredatlarına eklenen din, ahlak ve değerler alanı seçmeli derslerine bağlı olarak büyüyen din dersi öğretmeni ihtiyacı ve din görevlisi istihdamındaki hızlı artışla bir arada değerlendirilmesi gereken bu tablo, yüksek din öğretiminin giderek artan oranda bir meslek ve istihdam meselesi olarak algilanmasında önemli bir âmil olarak karşımıza çıkmaktadır. Bu bağlamda din eğitiminin; özellikle yüksek öğretim bağlamında birtakım meslekî görevleri yerine getirmeye yönelik malumat yığınından öte gitmeyen, öğrencinin ilgi ve motivasyonunu çekmeyen ve geçmek için çalışlan derslerin verildiği bir alan haline gelme riskiyle karşı karşıya olduğu akla gelmektedir (Köylü, 2014, s. 66-67).

Din eğitimi bağlamında etkileyici bir hitabetle vaaz vermek, güzel bir ses tonu ve beden diliyle namaz kıldırmak, Kurân-1 Kerim, ezan ve hutbeleri güzel bir üslupla kulağa hoş gelecek bir ses ve tavırla okumak, hiç kuşkusuz din eğitimi açısından değer ifade eden müstesna becerilerdir. Yaygın ve örgün anlamda din eğitimcisinin edinmesi gereken meslekî formasyonlar elbette ki etkili din eğitimi ve din hizmetlerinin yürütülmesinin gerek-şartıdır. Ancak bu formasyon nitelikleri, din eğitimcisinin dinî ve ahlâkî olgunluğunu belirleyen ihlas, samimiyet, özveri, sevgi, hoşgörü ve adanmışlık gibi hasletlerle tamamlanmadığında verilen eğitimin bir sosyal hizmet yahut memuriyet mantığı içerisinde sunulması sonucunu doğurabilir. Kocảnın (2012, s. 19) ifade ettiği gibi "Bir kimse bütün samimiyeti ile inanmadıkça ve bizzat bir davranış haline getirmedikçe, herhangi bir dinî konuyu başarılı ve inandırıı bir şekilde başkalarına anlatamaz". Dinî hakikatlerin değişen dünya 
ve insanlık karşısında yeni değerler oluşturmaya yönelik inceliklerini ve insan hayatına anlam veren yönlerini kavratmaya yönelik bir gayret olmaksızın biçimsel hassasiyetlerin istenen sonucu vermeyeceğini ifade etmek mümkündür.

Elbette ki ilahiyatın ve ilahiyatçının varoluş nedeni ya da nedenlerinden biri, din olgusu etrafında vuku bulan nazarî ve amelî sorunları araştırmak, bunlarla başa çıkacak uzmanlar yetiştirmek ve alternatif çözüm yolları bulmaktır (Nazıroğlu, 2020, s. 254). Yaygın din eğitiminden farklı olarak örgün din eğitimi, özellikle imam-hatip okulları ve ilahiyat fakültelerinde öğrencileri dinî alanda görev alacak bilgi ve birikimle donatmayı ve dinî alanda meslek edinmeyi sağlayacak formasyonu kazandırmayı da amaçlamalıdır. Bununla birlikte söz konusu eğitim kurumlarının misyon ve vizyon tanımları, sahip oldukları okul kültürü ve eğitim-öğretim anlayışları istihdam odaklı ve meslek kazandırma ağırlıklı olmaya başladığında; bu okulların müfredat içeriklerinin usûl, kaide ve esaslara ilişkin teknik bilgi ağırlıklı olması kaçınılmaz hale gelmektedir. Dinî bilgiyi gerek öğretim yöntemleri gerekse ölçme-değerlendirme süreçleri bağlamında diğer bilgi türleriyle eşitleyen ve bir işin nasıl yapılacağına ilişkin pratik bilgi-beceriyi, yani know-how’ı önceleyen bu araçsalcı ve teknik rasyonalite ile din eğitimciliği görevi; çoğu zaman amatör bir ruh, içtenlik ve gönüllülük esası içinde hareket etmeyi gerektiren doğasından uzaklaşarak dünyevî amaçlar için yapılır hale gelir. Din eğitiminin kariyer, unvan, kadro ve derece öncelikli, ayrıntılı bir şekilde hazırlanmış performans kriterlerine ve teknolojik-dijital yeterliliklere dayalı profesyonel bir anlayışa indirgenmesiyle din eğitimcisi; görev standartları sıkı sıkıya tanımlanmış, var olan sistemin olduğu gibi sürdürülmesinden sorumlu ve değişim/dönüşüme yönelik irade beyanından yoksun bir memur ya da bürokrat gibi davranmak zorunda kalacaktır. Bu zorunluluk; eğitimci kimliğinin finansal, eğitimsel, politik ve ideolojik bağlamlarda belirli bir özerklik ve bağımsızlık gerektiren karakterine zarar verecek niteliktedir. Bu bağlamda Kara’nın (2015, s. 431) "Dersime girerim, anlatır çıkarım, gerisi beni ilgilendirmez” diyen bir din eğitimcisi nesli ortaya çıktığına dair tespiti, üzerinde düşünülmeyi hak eden bir mesele olarak kaydedilmelidir. Teknik ve meslekî bakış açısının yol açtığı memur/bürokrat tavrının içselleştirilmesi, din eğitimcisi açısından öğrenciyi İslâmî bilgi ve değer müktesebatı yoluyla belirli bir ahlak ve mâneviyat ufkuna çekme ve bireyin potansiyelini açığa çıkararak ideal Müslüman tipini gerçekleştirme görevini profesyonel kaygılarının gerisine düşürme riskini beraberinde getirmektedir.

Bankacı eğitimin teknik ve meslekî bilgi odaklı bakış açısı bağlamında Altun'un (2019, s. 55) ve Çiftçi'nin (2017, s. 205) imam-hatip ve genel eğitim müfredatında okutulan seçmeli Kur'ân-ı Kerim dersleri üzerine yaptıkları çalışmaların sonuçları çarpıcıdır. Bu çalışmalarda din dersi öğretmenlerinin büyük çoğunluğu; derste bilgi seviyesinde çok fazla konunun bulunduğuna ve bu dersin Kur'ân'ı anlamaya değil, yüzünden okumaya yoğunlaşmış olduğuna dikkat çekmişlerdir (Altun, 2019, 
55; Çiftçi, 2017, 205). Dersin öğretim programında Kurân-1 Kerim’i severek ve isteyerek okumaya, anlamaya, hayatımızdaki yerini fark etmeye ve meâl kullanmaya yönelik vurgular yapılmış olmasına rağmen (MEB, 2012, ss. 2-3) ders içeriğinin ortaokul seviyesinde bile yöntem ve tarihsel bilgiye ilişkin çok fazla teknik detay içermesi, örgün düzeydeki Kurân eğitiminin teknik ve meslekî bilgi yönelimli olduğunu göstermektedir (bkz. Çakmak ve Ecer, 2020, 688; Koç ve Özkan, 2019, s. 223; Kaymakcan, 2013, 74-75). Yapılan bazı çalışmalarda bu durumun dersi veren öğretmenler açısından dahi sorun teşkil ettiği ve birçok öğretmenin kendilerini yetersiz hissettiğinden dolayı dersi vermekten imtina ettikleri ortaya çıkmıştır (bkz. Aşlamacı ve Gök, 2019, ss. 363; Nazıroğlu, 2014, s. 211). Kur'ân’ın anlaşılması ve hayata geçirilmesinden çok, nasıl daha doğru okunabileceğine ilişkin bilgiye yönelik bu tavır, din derslerini dünya ve ahiret saadetini kazanmaya yönelik duyarlılık kazandırma ve hayatını bu duyarlılık ile şekillendirmeyi öğretme misyonunun uzağına savurarak Kur'ân'ın anlaşılmasına, Hz. Peygamber'in mesajının kavranmasına ve İslam'ın kurtarıcı vizyonunun hayata geçirilmesine yönelik motivasyonları ikinci plana itmektedir.

Bu noktada Kurân eğitiminin niteliğinin arttırılması açısından eleştirel pedagojinin okuryazarlığa ilişkin özgün tavrını zikretmek faydalı olacaktır. Okuma ve yazma öğrenmeyi "sadece harfleri okuyup yazmayı öğrenmek değil, bunun yanı sıra kendi sözünü söyleme ve dünyayı kendisine sunulandan farklı bir biçimde adlandırmayı da öğrenmek" olarak tarif eden Freire (1995, s. 15), bu bağlamda okuma yazmanın mekaniğini, yani harflerin bir araya getirilmesi anlamındaki okuma yazma becerisini bir adım öteye taşıyarak okuryazarlığın hem sözcükleri hem de dünyayı okumak olarak anlaşılması gerektiğini ileri sürer. Bu açıdan okuryazarlık, "toplumdaki alt grupların özgürlüğe adım atmak ve toplumu güçlendirmek için gerekli bilgi ve becerileri edinebilecekleri bir siyasal ve kültürel yurttaşlık görevidir” (Freire, 2014, s. 14). Freire’nin 1960’lı yıllarda açtığı okuma yazma kurslarına katılan bir köylü, okuma yazma öğrendikten sonraki duygularını "Bir insan olduğumu şimdi anlıyorum. Körmüşüz, gözlerimiz açıldı. Bundan önce sözcükler bana bir şey söylemezdi, oysa şimdi benimle konuşuyorlar ve onları konuşturan kişi benim" sözleriyle ifade etmiştir (Freire, 1995, s. 15). Bu tarz bir okuma-yazma eğitimi nosyonunun din eğitimi açısından anlamı; Kurân kıraatinin, ibadetlerin ve çeşitli dinî pratiklerin öğretilmesinde şekilsel nitelikteki "nasıl” sorusuna ilişkin yanıtların yanı sıra söz konusu bilgi, amel ve ibadetlerin varlık sebebine ilişkin "niçin” sorusuna yanıt aranması gerektiğidir. Örnek verilecek olursa; Kur’ân eğitimi, ilahî mesajın özümsenmesi ve içselleştirilmesine yönelik bir anlayış bağlamında yeniden ele alınabilir ve bu suretle harflerin ve kelimelerin nasıl bir araya getirileceğini öğretmekten ibaret bir etkinlik olmanın ötesine geçebilir. Ezber öncelikli bir eğitim anlayışındansa öğrenciye Kurân kıssaları ve kelimeleri ile konuşmayı, bu kelimeleri konuşturmayı ve âyetlerin anlamlarını çeşitli örnek olaylar, güncel problemler ve öykülerle açıklayıp hayattaki karşılıklarıyla öğretmeyi önceleyen bir 
bakış açısının yerleşmesi; öğrencinin öğrendikleriyle "şu anda ve burada” olup bitmekte olan gerçekliği kendi sözcükleriyle adlandırmaları ve ardından hakka, hayra ve güzelliğe yönelik bir dönüşüme yönelmeleri açısından daha faydalı olacaktır. Bu tavır, okuma-yazma eylemini Allahû Teâlẩnın kavlî âyetlerini ihtiva eden Kur'ân-1 Kerîm ile kevnî âyetlerinin tezahür alanı olan dış dünya arasındaki bağlantının keşfedilebileceği bir diyalog ve iletişim vasıtasına dönüştürecektir. Böylece Kurân okumak; dünyayı okumayı, hatta yalnızca okumayı değil onu belirli biçimde yazmayı, yani bilinçli bir şekilde değiştirmeyi, dönüştürmeyi ve güzelleştirmeyi de ihtiva eden devingen bir süreç haline evrilerek özgürleştirici ve kurtarıcı bir eylem haline gelecektir.

\section{SONUÇ VE ÖNERILER}

Eğitimde bilgi, benimsenen öğretim yaklaşımlarının niteliğine göre kişilik inşa edici ve özgürleştirici olduğu kadar zihni durağanlaştırıcı ve kişiyi özne kılan yetileri pasifleştirici nitelik de kazanabilir. Yaratıcı ve eleştirel düşünceyi beslemeyen, ezber ve tekrara dayalı bilgi; eleştirel pedagojinin, kişiye hem kendisi hem de içinde yaşadığı toplum üzerindeki ideolojik ve politik etmenleri fark ettirme ve bu etmenlerin baskısından kurtulmaya yönelik eyleme teşvik etme amacı taşıyan insanlaştırıcı ve özgürleştici bilgi kategorisini karşılamaktan uzaktır. Bu nedenle din eğitimi faaliyetleri kapsamında öğretilecek bilgi; bankacı eğitimde depolanan, istif edilen ve aktarılan bir şey olarak görülen enformasyon kavramından farklı bir düzlemde ele alınmalıdır. Bireyin ve dünyanın dönüştürülmesi gibi dinamik bir hedef taşımayan, statik, değişmez ve durağan bir kalıba sokulmuş bir bilgi kavrayışı; din olgusunu belirli bir meslek, kariyer planlaması ya da görev kapsamında işlerliği olan teknik bilgi kategorisine hapsetmek anlamına gelecektir. Din eğitimcileri bilginin bu yönünü dikkate alarak kavramların ve tanımlamaların biriktirilmesinden ibaret olan teknik ve meslekî bilgi anlayışına hapsolmaktan kurtulmalı; Allah’n insanda yarattığı fitratın gerçekleşmesini sağlayan, insanın gizil güçlerini açı̆̆a çıkaran ve hayata anlam vermeyi teşvik eden dinamik bilgiyi öncelemelidir. Bu bağlamda ilahiyatçı, din görevlisi, din dersi öğretmeni, dinî rehber ve dinî danışman vb. meslek elemanlarını yetiştiren eğitim kurumlarının misyon ve vizyon tanımları, müfredatları, öğretim programları ve eğitim anlayışları yeniden değerlendirilerek bu görevlerin maaş, sosyal güvenlik ve belirli meslekî niteliklere sahip birer memuriyet vazifesi olarak algılanmasının önüne geçilmelidir. Din eğitimi etkinlikleri bu şekilde yalnızca belirli rutin ve pratiklere alıştırmaya, kişiyi topluma adapte etmeye ve statükoyla uyumlaştırmaya yönelik bir teknisyenlik faaliyeti olmaktan çıkarak aktif bir toplumsallık bilincine sahip bireylerin yetiştirilmesine ve fertlerin çağın baskı araçlarına karşı aydınlatılmasına yönelik bir görü kazanabilir.

Değer ve yaşantı yüklü bir kavram olarak din kavramı; hayata, insana ve dünyaya dair "halihazırda olan" kadar "olması gereken" ile de her dâim iç içedir. Burada, 
"olması gereken" ifadesiyle anlatılmak istenen; dinin yetiştirmeyi hedeflediği insan tipi ve kurmayı amaçladığ 1 toplumdur. Bu anlamda bireyin kendisini ve içinde yaşadığı toplumu fitrata uygun bir şekilde dönüştürmesini sağlayacak doğru eylemin, diğer bir ifadeyle sâlih amelin motivasyonu, pozitivist bağlamlı olgusal ve önermesel bilgi değildir. Bu nedenle din eğitiminde, geçmişte üretilmiş ve halihazırda üretilmekte olan bilgilere ilişkin olgusal ve görgül müktesebatın aktarılmasına dayalı pedagojik modellerin aşılması ve bireyi, "olması gerekene" ilişkin düşünce ve eylem motivasyonuyla besleyebilecek bir bilgi vizyonu tasarlanması gerekmektedir. Bu açıdan din eğitimi, nesnel bilgi arayışıyla gelen mâneviyattan uzak yönelimlere karşı hayatın içinden, organik ve insancıl bir bilgi anlayışıyla desteklenmeli ve İslam'ın aktif eylem ve irade tasavvuruna koşut bir şekilde bireyin Allah vergisi yetilerini optimum düzeyde çalıştırmaya yönelik eğitim-öğretim ortamları, müfredat içerikleri ve öğretim yöntemleriyle zenginleştirilmelidir. Din eğitimi etkinlikleri kapsamında oluşturulacak müfredatlar, kullanılacak yöntem-teknikler ve ölçme değerlendirme araçları öğrencinin günlük dünyevî deneyimler, sosyopolitik gerçeklikler ve somut insan durumları üzerinde düşünebilmesine imkân tanıyacak şekilde güncellenmelidir. Nicel araştırmalarla belirlenmiş sıradan ve ortalama yapıp etmeleri, alışkanlıkları ve tutumları kazandırmak üzerine kurulu din eğitimi yaklaşımları terk edilerek bunun yerine, bireyin tarih içinde yaşayan bir özne olarak söz söyleme ve eylemde bulunma kapasitesini destekleyen, besleyen ve teşvik eden bir yaklaşım geliştirilmelidir. Din eğitiminin ölçme ve değerlendirme süreçlerinde de dikkate alınması gereken bu durum bağlamında; test ve yazılı sınav gibi araçlara göre daha çok çaba ve zaman gerektirse de rekabetin ve sıralamanın asgariye indirildiği performans görevi, proje ödevleri, öz değerlendirme ve sözlü sunum gibi alternatif ölçme-değerlendirme araçlarına ağırlık verilmelidir. Öğretim süreçlerine gömülü, sürece dayalı ve öğrenme ile bütünleşik bir şekilde zamana yayılmış; derse katılım, yorum yapma, üretme, öğrenilenleri eleştiri süzgecinden geçirme ve güncel problemler bağlamında anlamlandırma, yaratıcılık, keşfetme, sorumluluk ve inisiyatif alma, girişimde bulunma ve uygulama gibi gerçek hayata dayalı kriterlerin dikkate alındığı ölçme ve değerlendirme süreçlerinin, özgürleştirici bir din eğitimi açısından tercih edilebilir nitelikte olduğu düşünülmektedir. 


\section{KAYNAKÇA}

Akpınar, Ali. “Tefsir ve Kur’ân Derslerinin Öğrencilerde "Kur’ân Kültürü”. Tefsir Eğitim ve Öğretiminin Problemleri. ed. Ömer Kara. 167-187. Istanbul: Kurav Yayınları, 2007.

Akyürek, Süleyman. "Bugünün Ilahiyatı Üzerine, Eleştirel Bir Değerlendirme?". Bugünün Ilahiyatı Nasıl Olmalıdır? Sorunlar ve Çözümleri. ed. Süleyman Akyürek. 351-369. Ankara: Ensar Yayınları, 2015.

Alaz, Ayşegül - Yarar, Seher. "Ölçme-Değerlendirme Sürecinde Sınıf Öğretmenlerinin Tercihleri ve Sebepleri”. ı. Uluslararası Türkiye Eğitim Araştırmaları Kongresi. Çanakkale: Eğitim Araştırmaları Birliği, 2009. http://www. eab.org.tr/eab/2009/pdf/139.pdf

Altaş, Nurullah. "Uzaktan Eğitim ve ILITAM Uygulamalarının Geleceği Nasıl Olmalıdır?” Bugünün Ilahiyatı Nasıl Olmalıdır? Sorunlar ve Çözümleri. ed. Süleyman Akyürek. 387-412. Istanbul: Ensar Neşriyat, 2015.

Altaş, Nurullah. “Yüksek Din Öğretiminde Uzaktan Eğitim Uygulamaları: ILITAM ve Sorunları”. Türkiye’de Din Eğitimi ve Sorunları. ed. Mustafa Köylü. 209-237. Istanbul: DEM Yayınları, 2018.

Altun, Mukadder. Öğretmen Görüşlerine Göre Seçmeli Kur'an Dersleri -Nitel Bir Araştırma. Rize: Recep Tayyip Erdoğan Üniversitesi Sosyal Bilimler Enstitüsü, Yüksel Lisans Tezi, 2019.

Aslan, Mecit - Kozikoğlu, Ishak. "Pedagojik Formasyon Eğitimi Alan Öğretmen Adaylarının Eleştirel Pedagojiye Ilişkin Görüşleri”. Abant Izzet Baysal Üniversitesi Eğitim Fakültesi Dergisi 15/1 (2015), 1-14. https://doi. org/10.17240/aibuefd.2015.15.1-5000128591

Aşlamacı, Ibrahim - Gök, Ömer Faruk. "Öğretmenlerine Göre Ortaokul Din, Ahlak ve Değerler Alanı Seçmeli Derslerinde Karşıllaşılan Sorunlar: Nitel Bir Araştırma”. derglabant (AiBü Ilahiyat Fakültesi Dergisi 7/14 (2019), 354-385. https://dergipark.org.tr/tr/download/article-file/868210

Bahar, Mehmet vd. Geleneksel-Tamamlayıcı Ölçme ve Değerlendirme Teknikleri. Ankara: Pegem Akademi Yayıncillk, 2014.

Baltacıoğlu, İsmayll Hakkı. T.B.M.M. Tutanak Dergisi Dönem:VIII Toplantl: 320 / (04 Haziran 1949), 227-284. https:/l www.tbmm.gov.tr/tutanaklar/TUTANAK/TBMM/d08/c020/tbmm08020101.pdf

Bayraktar, Kerim. Uzaktan Eğitim ve Din Öğretiminde Bir Uygulama Örneği: Ilahiyat Lisans Tamamlama (ILiTAM). Ankara: Ankara Üniversitesi Sosyal Bilimler Enstitüsü, Yüksek Lisans Tezi, 2010.

Bayraktutan, Talat Alp. Illahiyat Lisans Tamamlama (ILiTAM) Programına Ilişkin Öğrenci Görüşleri (Sivas Cumhuriyeti Örneği). Sivas: Cumhuriyet Üniversitesi Sosyal Bilimler Enstitüsü, Yüksek Lisans Tezi, 2021.

Berberoğlu, Giray. Sınıf Içi Ölçme Değerlendirme Teknikleri. Istanbul: Morpa Kültür Yayınları, 2006.

Bilgin, Beyza - Selçuk, Mualla. Din Öğretimi Özel Öğretim Yöntemleri. Ankara: Gün Yayıncılık, 2000.

Bilgin, Beyza. Eğitim Bilimi ve Din Eğitimi. Ankara: Gün Yayıncılık, 2001.

Buber, Martin. Ben ve Sen. çev. Inci Palsay. Ankara: Kitabiyat, 2003.

Cohen, Adir. "Martin Buber and Changes in Modern Education”. Oxford Review of Education 5/1 (Ocak 1979), 81-103. https://doi.org/10.1080/0305498790050108

Çakmak, Ahmet - Ecer, Münir. "Seçmeli Kur'an-ı Kerim Dersine Yönelik Motivasyon Ölçeğinin (SKKMÖ) Geliştirilmesi ve Çeşitli Değişkenler Açısından Incelenmesi”. Hitit Üniversitesi Ilahiyat Fakültesi Dergisi 19/2 (2020), 679-707. https://dergipark.org.tr/tr/download/article-file/1104871

Çakmak, Alaaddin. Din Kültürü ve Ahlak Bilgisi Öğretiminde Ölçme ve Değerlendirme Teknikleri ve Öğretmenlerin Bunları Kullanma Düzeyleri. Sakarya: Sakarya Üniversitesi Sosyal Bilimler Enstitüsü, Yüksek Lisans Tezi, 2011.

Çiçek, Hasan Basri. Güncellenen Ilköğretim Din Kültürü ve Ahlak Bilgisi Öğretim Programına Yönelik Öğretmen Görüşleri. Ağrr: Ibrahim Çeçen Üniversitesi Sosyal Bilimler Enstitüsü, Yüksel Lisans Tezi, 2019.

Çiftçi, Harun. Ortaokul Din, Ahlak ve Değerler Alanı Seçmeli Derslerinin Öğretmen, Öğrenci ve Veli Görüşleri ile Değerlendirilmesi. Ankara: Ankara Üniversitesi Sosyal Bilimler Enstitüsü, Yüksek Lisans Tezi, 2017.

Dağ, Mehmet. “ilahiyat Lisans Tamamlama (ILiTAM) Programlarında Kur'an Dersi -Müfredat, Materyal Hazırlama ve Karşılaşılan Sorunlar-“." EKEV Akademi Dergisi 17/55 (2013), 37-54.

Doğan, Recai. “lilahiyat Fakültelerinin Eğitim Anlayışı Nasıl Olmalıdır?” Bugünün ilahiyatı Nasıl Olmalıdır? Sorunlar ve Çözümleri. ed. Süleyman Akyürek. 351-369. Ankara: Ensar Yayınları, 2015.

Eliade, Mircea. Dinsel Inançlar ve Düşünceler Tarihi. çev. Ali Berktay. Istanbul: Kabalcı Yayınları, 2003.

Foucault, Michel. Hapishanenin Doğuşu. çev. Mehmet Ali Kılıçbay. Ankara: Imge Kitabevi, 1992.

Freire, Paulo. “The Adult Literacy Process as Cultural Action for Freedom”. Harvard Educational Review 40/2 (1970), 205-225.

Freire, Paulo. Ezilenlerin Pedagojisi. çev. Dilek Hattatoğlu - Erol Özbek. Istanbul: Ayrıntı Yayınları, 1995. 
Freire, Paulo. Yüreğin Pedagojisi. çev. Özgür Orhangazi. Ankara: Ütopya Yayınları, 2014.

Gümüş, Arife. Türk Eğitim Sisteminin Sınavlarla Imtihanı. IIlke Politika Notu. İstanbul: Illke Ilim Kültür ve Eğitim Vakfı, 2018. https://ilke.org.tr/images/yayin/pdf/turk_egitim_sisteminin_sinavlarla_imtihani.pdf

Gür, Bekir. Eğitimle Imtihan (2004-2013). Ankara: SETA Yayınları, 2017.

Habermas, Jürgen. Iletişimsel Eylem Kuramı. çev. Mustafa Tüzel. İstanbul: Kabalcı Yayınları, 2001.

Hussien, Suhailah. Towards the Islamisation of Critical Pedagogy: A Malaysian Case Study. Vol. II. United Kingdom: University of Sheffield Department of Educational Studies, Doktora Tezi, 2006. https://etheses.whiterose. ac.uk/4215/1/434500_vol2.pdf

Ibn Haldun. Mukaddime. çev. Süleyman Uludağ. 2 Cilt. İstanbul: Dergâh Yayınları, 2009.

Кага, Ömer. "Müzakereler". Bugünün Illahiyatı Nasıl Olmalıdır? Sorunlar ve Çözümleri. ed. Süleyman Akyürek. 424432. Ankara: Ensar Yayınları, 2015.

Karbeyaz, Pervin. Ilkokul ve Ortaokul Din Kültürü ve Ahlak Bilgisi Öğretmenlerinin Alternatif Ölçme ve Değerlendirme Tekniklerini Kullanma Düzeyleri ve Karşılaştıkları Sorunlar (Osmaniye Ili Örneği). Kilis: Kilis 7 Aralık Üniversitesi Sosyal Bilimler Enstitüsü, Yüksek Lisans Tezi, 2018.

Kaymakcan, Recep. "Din Eğitiminde Çoğulculuk ve Yapılandırmacılık”. Din Eğitiminde Çağdaş Konular. ed. Mustafa Köylü. 81-102. İstanbul: DEM Yayınları, 2012.

Kaymakcan, Recep vd. "Seçmeli Din Eğitimi Dersleri Inceleme ve Değerlendirme Raporu". İstanbul: DEM Yayınları, 2013.

Kayretli, Rafet - Oral, Ertuğrul. "Eğitimde Ezber Yönteminin Yeri Konusunda Yönetici ve Öğretmen Görüşleri”. Istanbul Sabahattin Zaim Üniversitesi Sosyal Bilimler Dergisi 2/4 (2014), 13-36. https://openaccess.izu. edu.tr/xmlui/bitstream/handle/20.500.12436/138/E\%C4\%9Fitimde\%20ezber\%20y\%c3\%B6nteminin\%20 yeri\%20konusunda\%20y\%C3\%B6netici\%20ve\%20\%c3\%B6\%C4\%9Fretmen\%20و\%С3\%B6r\%с3\%BC\%с5\%9Fleri?sequence=18isAllowed $=y$

Kılıç, Muharrem. "Dini Bilginin Doğruluğu Bağlamında Zâhirî Epistemolojinin Dayandığı Dil Kuramı”. Bilimname Dergisi II/ (2003), 157-169.

Kılıc, Recep. “Din Öğretimini Temellendirme Problemi”. Dini Araştırmalar 1/3 (Haziran 1999), 205-212. http://isamveri. org/pdfdrg/D01949/1999_3/1999_3_KILICR.pdf

Kılınç, Murat. Uzaktan Eğitim Uygulamalarının Etkililiği Üzerine Bir Araştırma (İnönü Üniversitesi Uzaktan Eğitim Merkezi Illahiyat Lisans Tamamlama Programı Örneği). Malatya: İönü Üniversitesi Eğitim Bilimleri Enstitüsü, Doktora Tezi, 2015.

Koca, Ferhat. "Din Görevlisi Cemaat Ilişkisi”. Diyanet Aylık Dergi 258 (Ekim 2008), 16-19. https://dosya.diyanet.gov. tr/flip/index.php?YIL=2008\&TR=17\&DERGI=ekim_2008.pdf\&SAYFANO=18

Koç, Ahmet - Özkan, Esma. “Örgün Din Eğitimi Veren Kurumlarda Kur'an-ı Kerim'in Anlamının Öğretilmesi Üzerine Bir Araştırma”. Yakın Doğu Üniversitesi İslam Tetkikleri Merkezi Dergisi 5/2 (2019), 187-232. https://dergipark. org.tr/tr/download/article-file/906889

Korkmaz, Mehmet. "Müzakereler”. Türkiye'de Din Eğitimi ve Sorunları. ed. Mustafa Köylü. 377. İstanbul: DEM Yayınları, 2018.

Köylü, Mustafa. "Gençlik ve Barış Eğitimi İslami Bir Yaklaşım”. Gençlik Dönemi ve Eğitimi. 227-255. İstanbul: Ensar Neşriyat, 2000. http://isamveri.org/pdfdrg/D073846/2000/2000_KOYLUM.pdf

Köylü, Mustafa. "Türkiye’de Yüksek Din Öğretimi: Nicelik mi Nitelik mi?” Din Eğitiminde Kalite. ed. Fahri Kayadibi. 59-81. İstanbul: DEM Yayınları, 2014.

Kur'ân-ı Kerîm Meâli. çev. Halil Altuntaş - Muzaffer Şahin. Ankara: Diyanet Işleri Başkanlığı Yayınları, 12. Basım, 2011.

Makdisi, George. Ortaçağ’da Yüksek Öğretim İslam Dünyası ve Hıristiyan Batı. çev. Ali Hakan Çavuşoğlu - Tuncay Başoğlu. İstanbul: Klasik Yayınları, 2018.

MEB. Ortä̈ğretim Kur’an-ı Kerim Dersi (9-12. Sınıflar) Öğretim Programı. Ankara: MEB Yayınları, 2012.

MEB. Öğretmenlik Mesleği Genel Yeterlilikleri. Ankara: Öğretmen Yetiştirme ve Geliştirme Genel Müdürlüğü, 2017. http://oygm.meb.gov.tr/meb_iys_dosyalar/2017_12/11115355_YYRETMENLYK_MESLEYY_GENEL_ YETERLYKLERY.pdf

MEB. Din Kültürü ve Ahlak Bilgisi Dersi Öğretim Programı (ilkokul 4 ve Ortaokul 5, 6, 7 ve 8. Sınıflar). Ankara: MEB Yayınları, 2018a. https://dogm.meb.gov.tr/meb_iys_dosyalar/2018_05/15104708_201813015378536DKAB_9-12._SYחYf__DOP__2018.pdf 
MEB. Din Kültürü ve Ahlak Bilgisi Dersi Öğretim Programı (Ortaöğretim 9, 10, 11 ve 12. Sınıflar). Ankara: MEB Yayınları, 2018b. https://dogm.meb.gov.tr/meb_iys_dosyalar/2018_05/15104708_201813015378536DKAB_9-12._SYnYf__DOP__2018.pdf

MEB. Öğretim Programlarını Değerlendirme Raporu. Ankara: MEB Yayınları, 2020. https://ttkb.meb.gov.tr/meb_ iys_dosyalar/2020_08/24113242_ogretimprogramlari_dr.pdf

Mehmedoğlu, Yurdagül. “ilahiyat Fakültesi Öğrencilerinin Eğitim-Öğretim Beklentileri”. Gençlik Dönemi ve Eğitimi. 121-150. Istanbul: Ensar Neşriyat, 2000. http://isamveri.org/pdfdrg/D073846/2000/2000_MEHMEDOGLUY. pdf

Memon, Nadeem - Ahmad, Qaiser. "The Pedagogical Divide: Toward an Islamic Pedagogy”. ISNA Education Forum 2006 Rosemont Illinois. 2006. https://farooq.files.wordpress.com/2007/05/nadeem_memon_and_qaiser_ ahmad_2006_-_the_pedagogical_divide.pdf

Nazıroğlu, Bayramali. İslam Eğitim Geleneğinde Öğretmenlik. Ankara: Sarkaç Yayınları, 2011.

Nazıroğlu, Bayramali. “Din Eğitiminde Sorunlar ve Çözüm Önerileri: Din Eğitimi ABD 16. Koordinasyon Toplantısı Izlenimleri”. Recep Tayyip Erdoğan Üniversitesi Ilahiyat Fakültesi Dergisi $3 / 5$ (2014), 203-228. https:// dergipark.org.tr/tr/download/article-file/285893

Nazıroğlu, Bayramali. Derdimiz Ilahiyat. İstanbul: OkurAkademi, 2020.

Okumuşlar, Muhiddin. Yapılandırmacı Yaklaşım ve Din Eğitimi. Konya: Yediveren Yayınları, 2014.

Rahath, Yousef - Hashim, Rosnani. "Contemporary Islamic Educational Discourse and the Philosophy of Empowerment". American Journal of Islamic Social Sciences 30/3 (Temmuz 2013), 20-38. https://www.ajis. org/index.php/ajiss/article/view/300/2045

Rahman, Fazlur. İslam. çev. Mehmet Dağ - Mehmet Aydın. İstanbul: Selçuk Yayınları, 1993.

Rahman, Fazlur. "Islamization of Knowledge: A Response”. Islamic Studies 50/3/4 (2011), 449-457.

Roberts, Peter. "Critical Literacy, Breadth of Perspective and Universities: Applying Insights from Freire”. Studies in Higher Education 21/2 (1996), 149-163. http://www.acervo.paulofreire.org/bitstream/handle/7891/790/ FPF_PTPF_01_0239.pdf?sequence=28isAllowed=y

Selçuk, Mualla. “Din Öğretimi Özgürleştiren Bir Süreç Olabilir mi?” İslamiyat Dergisi 1/1 (1998), 73-87.

Şenat, Fatma Asiye. “Ilahiyat Fakültesi Öğrencilerinin Kur’an Okuma ve Tecvid Dersinin Işlenişiyle Illgili Kanaatleri Üzerine Bir Araştırma”. Necmettin Erbakan Üniversitesi Ilahiyat Fakültesi Dergisi $42 / 42$ (Aralık 2016), 215-238. https://dergipark.org.tr/tr/download/article-file/337931

Taşdemirci, Ersoy. “Osmanlı Imparatorluğu’nda Medreseler”. Erciyes Üniversitesi Sosyal Bilimler Enstitüsü Dergisi 2 (1989), 269-271.

Topçu, Nurettin. Türkiye’nin Maarif Davası. İstanbul: Dergâh Yayınları, 1997.

Ulu, Anıl. Ilköğretim Din Kültürü ve Ahlak Bilgisi Öğretmenlerinin Derslerinde Kullandıkları Ölçme ve Değerlendirme Teknikleri ile Programın Önerdiği Tekniklerin Karşılaştırılması. Ankara: Ankara Üniversitesi Sosyal Bilimler Enstitüsü, Yüksek Lisans Tezi, 2011.

Yapıcı, Asım. "Müzakereler”. Bugünün Illahiyatı Nasıl Olmalıdır? Sorunlar ve Çözümleri. ed. Süleyman Akyürek. 7679. Ankara: Ensar Yayınları, 2015.

Yaran, Cafer Sadık. “Insanın Egzistansiyal ihtiyaçları ve Dinin Perenniyal Cevapları”. Ondokuz Mayıs Üniversitesi Ilahiyat Fakültesi Dergisi 12/12-13 (01 Nisan 2001), 79-96. https://dergipark.org.tr/tr/download/articlefile/188615

Yılmaz, Zafer. Paulo Freire’nin Felsefesinde Özgürleşmenin Aracı Olarak Eğitim. FLSF (Felsefe ve Sosyal Bilimler Dergisi), 22, (2016), 199-313.

YÖK. Öğrenim Düzeyleri ve Birimlere Göre Öğrenci Sayıları, 2020-2021 Öğretim Yılı Yükseköğretim İstatistikleri (30 Eylül 2021). https://istatistik.yok.gov.tr/

Zengin, Mahmut. Yapılandırmacılık ve Din Eğitimi, Ilıköğretim DKAB Öğretim Programlarının Değerlendirilmesi ve Öğretmen Görüşleri Açısından Etkililiği. İstanbul: Marmara Üniversitesi Sosyal Bilimler Enstitüsü, Doktora Tezi, 2010. 